NBER WORKING PAPER SERIES

\title{
WAGE INEQUALITY AND FIRM GROWTH
}

Holger M. Mueller

Paige P. Ouimet

Elena Simintzi

Working Paper 20876

http://www.nber.org/papers/w20876

\author{
NATIONAL BUREAU OF ECONOMIC RESEARCH \\ 1050 Massachusetts Avenue \\ Cambridge, MA 02138 \\ January 2015
}

We thank Xavier Giroud and Johannes Stroebel for valuable comments and Raymond Story at Income Data Services (IDS) for help with the data. The views expressed herein are those of the authors and do not necessarily reflect the views of the National Bureau of Economic Research.

NBER working papers are circulated for discussion and comment purposes. They have not been peerreviewed or been subject to the review by the NBER Board of Directors that accompanies official NBER publications.

(C) 2015 by Holger M. Mueller, Paige P. Ouimet, and Elena Simintzi. All rights reserved. Short sections of text, not to exceed two paragraphs, may be quoted without explicit permission provided that full credit, including $\left({ }^{\circ}\right.$ notice, is given to the source. 
Wage Inequality and Firm Growth

Holger M. Mueller, Paige P. Ouimet, and Elena Simintzi

NBER Working Paper No. 20876

January 2015

JEL No. J24,J31

\begin{abstract}
$\underline{\text { ABSTRACT }}$
We examine how within-firm skill premia-wage differentials associated with jobs involving different skill requirements-vary both across firms and over time. Our firm-level results mirror patterns found in aggregate wage trends, except that we find them with regard to increases in firm size. In particular, we find that wage differentials between high- and either medium- or low-skill jobs increase with firm size, while those between medium- and low-skill jobs are either invariant to firm size or, if anything, slightly decreasing. We find the same pattern within firms over time, suggesting that rising wage inequality-even nuanced patterns, such as divergent trends in upper- and lower-tail inequality-may be related to firm growth. We explore two possible channels: i) wages associated with "routine" job tasks are relatively lower in larger firms due to a higher degree of automation in these firms, and ii) larger firms pay relatively lower entry-level managerial wages in return for providing better career opportunities. Lastly, we document a strong and positive relation between within-country variation in firm growth and rising wage inequality for a broad set of developed countries. In fact, our results suggest that part of what may be perceived as a global trend toward more wage inequality may be driven by an increase in employment by the largest firms in the economy.
\end{abstract}

Holger M. Mueller

Stern School of Business

New York University

44 West Fourth Street

Suite 9-190

New York, NY 10012-1126

and NBER

hmueller@stern.nyu.edu

Paige P. Ouimet

Kenan-Flagler Business School

University of North Carolina at Chapel Hill

Paige_Ouimet@kenan-flagler.unc.edu

\author{
Elena Simintzi \\ University of British Columbia \\ Sauder School of Business \\ 2053 Main Mall \\ Vancouver \\ V6T 1 Z2 \\ Canada \\ elena.simintzi@sauder.ubc.ca
}




\section{Introduction}

A simple model of skill premia based on shifts in skill supply in conjunction with a steady increase in skill demand, goes a long way toward explaining the rise in wage inequality over the past decades. ${ }^{1}$ Much less is known about how skill premia-wage differentials associated with jobs involving different skill requirements - are determined inside the firm. For instance, within a given firm, how much does a high-skill job, such as Human Resources Director, pay relative to a lower-skill job, such as Human Resources/Personnel Assistant? And does this wage differential vary across firms and over time? Understanding the determinants of skill premia is important, as it might help us better understand their variation and thus shed additional light on the causes of rising wage inequality. ${ }^{2}$

A challenge in analyzing skill premia lies in their measurement. Conventional skill measures, such as education or experience, are adequate if there is a one-to-one mapping between workers' skills and job tasks. In practice, however, workers with the same skill endowment (e.g., college education) may perform a variety of different job tasks, all with different skill requirements. Conversely, a given job task may be performed by workers with vastly different skill endowments. Drawing on this distinction between workers' skills and job tasks, Acemoglu and Autor (2011) argue that a richer, "task-based" framework in which skills are endogenously assigned to job tasks is needed to understand recent labor market developments, including the role of technological change and offshoring for employment and wages. ${ }^{3}$

An alternative approach involves using occupations to measure skill premia. What is appealing about occupations is that they are conceptually closer to job tasks. And yet,

\footnotetext{
${ }^{1}$ See Katz and Murphy (1992), Autor, Katz and Krueger (1998), Card and Lemieux (2001), Acemoglu (2002), Goldin and Katz (2007), Autor, Katz and Kearney (2008), and Acemoglu and Autor (2011). The model is attributed to Tinbergen's $(1974,1975)$ pioneering work on the race between education (skill supply) and technology (skill demand).

${ }^{2}$ In a similar vein, Autor (2014a, p. 843) speaks of the "centrality of the rising skill premium to the overall growth of earnings inequality."

${ }^{3}$ Acemoglu and Autor (2011), building on earlier models by Acemoglu and Zilibotti (2001), Autor, Levy, and Murnane (2003), and Costinot and Vogel (2010), develop a task-based model in which workers' skills, technology, and trade/offshoring are competing inputs for performing various tasks. As in Ricardian trade models, the equilibrium assignment of inputs to tasks depends on comparative advantage.
} 
issues similar to those discussed above also arise here. That is, workers within a given occupation may perform a variety of different job tasks, all with different skill requirements. Conversely, jobs with similar skill requirements may be performed by workers with vastly different occupational backgrounds. Indeed, we find both statements to be true in our data, that is, there is no simple one-to-one mapping between occupations and skill requirements.

This paper uses a proprietary data set of UK firms in which wages are observed at the job title-firm-year level. Important for our purposes, job titles are grouped into broader "job level" categories - groups of jobs with similar skill requirements. Thus, our data allow us to observe how much a given firm pays for jobs with particular skill requirements in a given year. For example, job level 1, our lowest skill category, includes work that "requires basic literacy and numeracy skills and the ability to perform a few straightforward and short-term tasks to instructions under immediate supervision." Typical job titles are cleaner, labourer, and unskilled worker. The second lowest skill category, job level 2, includes work that "requires specific administrative, practical, craft or technical skills gained by previous experience and qualifications to carry out a range of less routine work and to provide specialist support, and could include closer contact with the public/customers." Typical job titles are administrative assistant, driver, and operator. And job level 3, the third lowest skill category, includes work that "requires broad and deep administrative, technical or craft skills and experience to carry out a wider range of activities including staff supervision, undertaking specialist routines and procedures and providing some advice." Typical job titles are technician, craftsman, and skilled worker. Altogether, there are nine distinct job levels representing different levels of a firm's hierarchy. Not surprisingly, wages are increasing with job levels, suggesting that firms pay more for jobs with higher skill requirements.

Our main results examine how within-firm skill premia - wage differentials associated with jobs involving different skill requirements - vary both across firms and over time. We compute skill premia as ratios of wages associated with different job levels, and thus different skill requirements, within a given firm and year. Thus, a firm-year observation of, say, "wage ratio 12 " is the wage associated with job level 2 divided by the wage associated 
with job level 1 within the same firm and year.

Popular measures of (overall) wage inequality, such as the 90/10 log wage differential, compare wages from the top and bottom of the aggregate wage distribution. In our case, wage ratios such as 18, 28, 19, or 29 also compare top and bottom earners. However, this comparison is made within firms, meaning it is unaffected by firm composition effects. Perhaps more important, our wage ratios can be directly interpreted as skill premia, as they are constructed from different skill categories.

When examining "top-bottom" (e.g., 18, 28, 19, or 29) wage ratios, we find that they all increase with firm size. This is true regardless of whether we measure firm size by the number of employees (our base specification) or firms' sales. It is also true if we focus exclusively on within-industry variation. The effect is economically large. For example, moving from the 25 th to the 75 th percentile of the firm-size distribution raises the wage associated with job level 9 by $280.1 \%$ relative to the wage associated with job level 1 . Observe that this effect is different from the well-documented employer size-wage effect (e.g., Brown and Medoff (1989), Oi and Idson (1999)). The latter shows that wages are increasing with firm size. By contrast, our results show that wage differentials - in fact, within-firm skill premia - are increasing with firm size.

As several studies have noted, the rise in wage inequality - both in the UK and the US - has not been uniform. While overall (e.g., 90/10) and "upper-tail" (e.g., 90/50) inequality have risen steadily, "lower-tail" (e.g., 50/10) inequality has remained flat or, if anything, contracted slightly. ${ }^{4}$ We find the exact same pattern in our data, except that we find it with regard to increases in firm size. We already mentioned that "top-bottom" wage ratios increase with firm size. Similarly, we also find that "top-middle" (e.g., 48, 49, 58, or 59) wage ratios increase with firm size. In contrast, "middle-bottom" (e.g., 14, 15, $24,25)$ wage ratios do not increase with firm size. They either remain flat or, if anything, decrease slightly. Overall, our results suggest that rising wage inequality - even nuanced patterns, such as divergent trends in upper- and lower-tail inequality - may be related to firm growth.

\footnotetext{
${ }^{4}$ In the US, upper- and lower-tail wage inequality begin to diverge in the late 1980s. In the UK, they begin to diverge a decade later. See Section 5.1 for details.
} 
To explore what is driving these results, we revisit the employer size-wage effect. That is, we analyze wage levels instead of wage ratios. We find that wages in high-skill job categories (job levels 6 to 9) all increase with firm size. Moreover, the rate of increase is greater for higher skill categories. In contrast, wages in low- and medium-skill job categories (job levels 1 to 5) do not increase with firm size; they are either invariant to firm size or, if anything, slightly decreasing. This suggests two things. First, while the employer size-wage effect also "holds" in our data - wages increase with firm size on average - it is entirely driven by the upper tail of the skill distribution. Second, and more important, the invariance of middle-bottom wage ratios to firm size is not driven by wages in medium- and low-skill job categories both increasing at a similar rate. Rather, wages in both skill categories are individually invariant to firm size.

Why do wages in high-skill job categories increase with firm size but not wages in low- and medium-skill job categories? One possible explanation is that there exist countervailing mechanisms putting downward pressure on wages in low- and medium-skill job categories at larger firms, offsetting the general tendency of wages to increase with firm size. We focus on two such mechanisms. The first, building on seminal work by Autor, Levy, and Murnane (2003), posits that wages associated with "routine" job tasks are relatively lower in larger firms due to a higher degree of automation in these firms. Consistent with this hypothesis, we find that wages associated with routine jobs decline relative to those associated with non-routine jobs as firms become larger, especially in medium-skill job categories. The second mechanism posits that larger firms pay relatively lower entrylevel managerial wages in return for providing better career opportunities. Consistent with this hypothesis, we find that managerial wages in low- to medium-skill job categories are relatively lower in larger firms, while those in high-skill job categories are relatively higher in larger firms.

In the final part of our firm-level analysis, we examine within-firm changes in skill premia. In line with our previous results, we find that within-firm wage differentials between high- and either medium- or low-skill job categories rise as firms grow larger, while those between medium- and low-skill job categories remain unaffected.

We lastly explore whether wage inequality and firm growth are related at the country 
level. In this regard, the question is: growth of what firms? As we argue in the paper, when thinking about the relation between wage inequality and firm growth, one should not be thinking about the median firm in the economy. The median firm in the US had 0-4 employees in 1992 and still has 0-4 employees today. Rather, the relation between wage inequality and firm growth is likely driven by larger firms. To this end, we focus on the 50 or 100 largest firms per country using a broad sample of developed countries that includes the UK and US. We find evidence of strong firm growth among larger firms in practically all of these countries. Most important, we find that within-country variation in firm growth is positively and significantly related to rising wage inequality, even after accounting for common time trends. In fact, our results suggest that part of what may be perceived as a global trend toward more wage inequality may be driven by an increase in employment by the largest firms in the economy.

Altogether, our results suggest that firm growth, especially of larger firms, may contribute to rising wage inequality in two ways. First, it may act as a catalyst for already existing explanations that, as such, are not necessarily linked to firm growth. For instance, explanations for the divergent trends in upper- and lower-tail wage inequality based on the automation of routine job tasks (e.g., Autor, Katz, and Kearney (2006), Acemoglu and Autor (2011)) do not require firm growth. However, if larger firms are more likely to automate routine job tasks, then firm growth may act as a catalyst for task-replacing technological change. Second, firm growth may contribute to rising wage inequality through channels that are inherently linked to firm size. For instance, if larger firms exhibit wider spreads between top- and entry-level wages, then firm growth may directly contribute to rising wage inequality through this channel.

The rest of this paper is organized as follows. Section 2 presents the data and summary statistics. Section 3 examines how within-firm skill premia and wages per skill category vary with firm size. Section 4 considers the role of automation of routine job tasks and managerial career opportunities for skill premia. Section 5 explores within-firm changes in skill premia and examines the relation between wage inequality and firm growth for a broad set of developed countries. Section 6 concludes. 


\section{Data and Summary Statistics}

\subsection{Pay-Level Data}

We have comprehensive firm-level data on employee pay for a broad cross-section of UK firms for the years 2004 to 2013. The data are provided by Income Data Services (IDS), an independent research and publishing company specializing in the field of employment. IDS was established in 1966 and acquired by Thomson Reuters (Professional) UK Limited in 2005. It is the leading organization carrying out detailed monitoring of firm-level pay trends in the UK, providing its data to various public entities, such as the UK Office for National Statistics (ONS) and the European Union.

IDS gathers information on employee pay associated with various job titles within a firm. Firms are typically sampled multiple times. Sampled job titles may differ across firms. Important for our purposes, employers are asked to group job titles into broader "job level" categories based on the skills required for the job. Thus, job levels are categories of jobs with similar skill requirements. By implication, given job titles may be assigned to different job levels if they involve jobs with different skill requirements. This is especially relevant across different employers, where given job titles may have different meanings. IDS provides ten job levels in total, which can be broadly viewed as representing different levels of a firm's hierarchy. To increase the sample size in some of our regressions, we combine the lowest two job levels into a single job level, implying that we have nine job levels altogether. ${ }^{5}$

Table 1 provides descriptions of all nine job levels along with examples of typical job titles. For instance, job level 1, our lowest skill category, includes work that "requires basic literacy and numeracy skills and the ability to perform a few straightforward and shortterm tasks to instructions under immediate supervision." Typical job titles are cleaner, labourer, and unskilled worker. The second lowest skill category, job level 2, includes work that "requires specific administrative, practical, craft or technical skills gained by

\footnotetext{
${ }^{5}$ The results with the original ten job levels are provided in Appendix Table A1. As can be seen, except for the small sample size in some of the regressions involving the original job levels 1 and 2, all results are qualitatively similar.
} 
previous experience and qualifications to carry out a range of less routine work and to provide specialist support, and could include closer contact with the public/customers." Typical job titles are administrative assistant, driver, and operator. And job level 3, the third lowest skill category, includes work that "requires broad and deep administrative, technical or craft skills and experience to carry out a wider range of activities including staff supervision, undertaking specialist routines and procedures and providing some advice." Typical job titles are technician, craftsman, and skilled worker.

\section{$2.2 \quad$ Firm Size}

To obtain measures of firm size, we match the IDS firm names to Bureau van Dijk's Amadeus database. Amadeus provides financial information about public and private firms in the UK and other European countries. That Amadeus includes private firms is especially important for us, because $40 \%$ of the firms in our sample are private. All matches have been checked by IDS employees who are familiar with the sample firms. Our matching success rate is $90 \%$, providing us with a sample of 880 firms.

Our main measure of firm size is the number of employees. However, our results are similar if we measure firm size using firms' sales (see Appendix Table A2). As is typical of samples that include private and public firms, the firm-size distribution is heavily rightskewed due to the presence of some very large, public firms. To avoid that outliers drive our results, we winsorize firm size at the $5 \%$ level. Our results are similar if we winsorize firm size at the $1 \%$ level (see Appendix Table A3). ${ }^{6}$

The average firm in our sample is 32 years old, has 10,014 employees, book assets of 1,890 million GBP, and sales of 1,610 million GBP. There is considerable variation in firm size. For example, moving from the 25 th percentile (381 employees) to the median (1,705 employees) of the firm-size distribution involves an increase in firm size of $348 \%$, and moving from the median to the 75 th percentile (6,345 employees) involves a further increase

\footnotetext{
${ }^{6}$ The non-winsorized firm-size distribution has a median of 1,705 employees, mean of 12,606 employees, maximum of 508,714 employees, and skewness of 7.19. With 1\% winsorizing, the distribution remains heavily right-skewed: mean of 11,844 employees, maximum of 273,024 employees, and skewness of 5.21. The $5 \%$ winsorized distribution has a mean of 10,014 employees, maximum of 97,300 employees, and skewness of 3.03 .
} 
of $272 \%$. Firms are also widely dispersed across industries. The five largest industry categories in our sample are manufacturing (SIC 20-39, 29.8\% of firms), services (SIC 70-89, $23.1 \%$ of firms), transportation, communication, electric, gas, and sanitary services (SIC 40-49, 16.6\% of firms), finance, insurance, and real estate (SIC 60-67, $14.9 \%$ of firms), and wholesale and retail trade (SIC 50-59, 12.2\% of firms). None of our results are driven by industry composition effects. Indeed, all our results hold if we focus exclusively on within-industry variation (see Appendix Table A4).

\subsection{Descriptive Statistics}

Table 2 shows the distribution of wages for each job level, or skill category, based on all firm-year observations. Wages are deflated using the consumer price index (CPI) provided by the UK Office for National Statistics (ONS) and winsorized at the $1 \%$ level. As can be seen, wages are increasing with job levels, suggesting that firms pay more for jobs with higher skill requirements. For instance, the average wage in job level 1, our lowest skill category, is 13,778 GBP, the average wage in job level 5 is 29,352 GBP, and the average wage in job level 9, our highest skill category, is 110,693 GBP. Moving up one

level raises the average wage per job level by $29.8 \%$ on average, albeit the magnitude of this differential varies. In particular, at lower job levels (1 to 3), moving up one level involves a smaller increase (16.3\% to $20.8 \%$ ) than does moving up at medium or higher job levels (4 to 8$)(28.7 \%$ to $60.5 \%$ ). Thus, wages are increasing with job levels, but the rate of increase is larger at medium and higher levels.

Our main focus is on skill premia - within-firm wage differentials associated with different job levels. Specifically, we compute for all $(9 \times 8) / 2=36$ job-level pairs the corresponding ratio of wages within a given firm and year. Thus, a firm-year observation implies that we observe wages for both job levels in that particular firm and year. For ease of comparison, we always divide wages associated with higher job levels by wages associated with lower job levels, e.g., "wage ratio 12" means that we divide the wage associated with job level 2 by the wage associated with job level 1 .

Table 3 shows the distribution of skill premia for all 36 job-level pairs. For instance, 
an average wage ratio of 8.286 associated with job-level pair 19 implies that the wage associated with job level 9 is on average 8.286 times the wage associated with job level 1 when both wages are observed in the same firm and year. This is similar to the ratio of average wages (as opposed to the average wage ratio) from Table 2, where the average wage across all firms and years associated with job level 9 is $110,693 / 13,778=8.034$ times the average wage associated with job level 1.

As one might expect, average wage ratios are increasing with the distance between job levels. For instance, wage ratio 12 is lower than wage ratio 13, which is lower than wage ratio 14 . Likewise, wage ratio 34 is lower than wage ratio 24 , which is lower than wage ratio 14. Finally, holding the distance between job levels fixed, average wage ratios are higher when both job levels increase. For instance, wage ratio 13 is lower than wage ratio 24 , which is lower than wage ratio 35 .

Table 3 also shows the percentage of firm-year observations for which a given wage ratio exceeds one. This percentage is always close or equal to 100\%, suggesting that higher skill requirements are reflected in higher pay within a given firm and year. Indeed, only $2.2 \%$ of firm-year observations have wage ratios of less than one. Dropping these observations does not affect our results. ${ }^{7}$

When collecting wage data, IDS may not sample all job levels within a given firm in the same year. In particular, low $(1,2,3)$ and high $(8,9)$ job levels are often sampled in different years, with the implication that job-level pairs involving both levels, such as 19, 29, or 39, may have relatively fewer observations. This raises two potential issues: i) lack of statistical power, and ii) insufficient variation. As we will see below, neither is a serious concern. In fact, to the extent that we obtain insignificant results, this is always in conjunction with regressions that have sufficiently many observations.

\footnotetext{
${ }^{7}$ That some firm-year observations have wage ratios of less than one suggests that skill requirements are an important, but not the only, determinant of employee pay.
} 


\section{Skill Premia and Firm Size}

\subsection{Main Results}

Table 4 contains our main results. For each job-level pair, we regress the corresponding wage ratio, or skill premium, on firm size (both in logs). That is, we run 36 separate regressions. As it turns out, there is a clear pattern in the data.

Panel A includes all job-level pairs in which job level 1 is compared to higher job levels. Moving from left to right, the distance between job levels (i.e., the wage ratio) increases. As can be seen, the coefficient on firm size is initially insignificant (wage ratios $12,13,14$, and 15). Beginning with wage ratio 16, the coefficient is positive and significant (wage ratios 16, 17, 18, and 19). Moreover, when the coefficient is significant, it is also monotonically increasing in the wage ratio. For example, a one percent increase in firm size implies that the wage associated with job level 6 increases by $0.0375 \%$ relative to the wage associated with job level 1. By contrast, for the same increase in firm size, the wage associated with job level 7 increases by $0.0883 \%$, the wage associated with job level 8 increases by $0.162 \%$, and the wage associated with job level 9 increases by $0.179 \%$ - all relative to the wage associated with job level 1 . Thus, a one percent increase in firm size has a roughly five times bigger effect on wage ratio 19 than on wage ratio 16.

Panels B to D include all job-level pairs in which job levels 2, 3, or 4 are compared to higher job levels. The pattern is similar to Panel A. Precisely, the coefficient on firm size is initially insignificant (or, in one case (wage ratio 23), negative and significant) and then always positive and significant. Moreover, when the coefficient is significant, it is also monotonically increasing in the wage ratio. ${ }^{8}$ Finally, Panels $\mathrm{E}$ to $\mathrm{H}$ include all job-level pairs in which job levels $5,6,7$, or 8 are compared to higher job levels. The pattern is again similar, except that there is no initial region in which the coefficient on firm size is insignificant. That is, the coefficient on firm size is always positive and significant, and it is always monotonically increasing in the wage ratio.

In sum, even though we run 36 separate regressions, there is a clear pattern in the

\footnotetext{
${ }^{8}$ There is one minor exception: in Panel $\mathrm{D}$, the coefficient on firm size decreases slightly between wage ratios 48 and 49 (from 1.05 to 1.02).
} 
data. When low job levels (1 to 5) are compared to one another, an increase in firm size has no effect on within-firm skill premia. In contrast, when high job levels (6 to 9) are compared to either one another or low job levels, an increase in firm size widens the wage gap between higher and lower skill categories. This effect is stronger the greater is the distance between skill categories. For instance, moving from the 25 th to the 75 th percentile of the firm-size distribution - an increase in firm size of 1,565\% — raises the wage associated with job level 9 by $280.1 \%$ relative to the wage associated with job level 1 . By contrast, for the same increase in firm size, the wage associated with job level 6 increases only by $59.7 \%$ relative to the wage associated with job level 1 .

Our results are not driven by industry composition effects. In fact, as we show in Appendix Table A4, all our results hold if we focus exclusively on within-industry variation. If anything, the only noteworthy difference is that in two cases (wage ratios 24 and 25) the coefficient on firm size is negative and significant while it was previously negative and insignificant. As is shown in Appendix Table A2, our results are also similar if we measure firm size using firms' sales in lieu of the number of employees. Sales are measured in logs and deflated using the consumer price index (CPI) provided by the UK Office for National Statistics (ONS). Again, the only noteworthy difference is that in two cases (wage ratios 24 and 25) the coefficient on firm size is negative and significant while it was previously negative and insignificant. Finally, our results are also not driven by our choice of combining the lowest two IDS job levels into a single job level (see Appendix Table A1) or winsorizing (see Appendix Table A3).

As we already mentioned in the Introduction, there is a strong resemblance between our results and patterns found in aggregate wage data. Specifically, both in the UK and the US, there has been a "polarization" of wage trends: while overall (e.g., 90/10) and "upper-tail" (e.g., 90/50) wage inequality have risen steadily, "lower-tail" (e.g., 50/10) wage inequality has remained flat or, if anything, contracted slightly (see Section 5.1). We find the exact same pattern in our data, except that we find it with regard to increases in firm size. That is, "top-bottom" (e.g., 18, 28, 19, or 29) and "top-middle" (e.g., 48, 49, 58, or 59) wage ratios both increase with firm size, while "middle-bottom" (e.g., 14, 15, $24,25)$ wage ratios remain flat or, in some cases, decrease slightly. Overall, this suggests 
that rising wage inequality - even nuanced patterns, such as divergent trends in upperand lower-tail inequality - may be related to firm growth. We explore this hypothesis in more detail below.

\subsection{The Employer Size-Wage Effect Revisited}

The invariance of middle-bottom wage ratios with regard to firm size raises questions. Are wages in medium- and low-skill job categories both invariant to firm size? Or do they merely increase (or decrease) at a similar rate? To address these questions, we next revisit the employer size-wage effect. That is, we analyze wage levels (in logs) instead of wage ratios.

Table 5 presents the results. The first column, which combines all job levels, includes job-level fixed effects. Thus, the comparison is between small and large firms within a given job level, or skill category. As can be seen, the employer size-wage effect also "holds" in our data. Across all job levels, a one percent increase in firm size implies an average wage increase of $0.0126 \%$. This magnitude is very similar to the company size-wage effect in Brown and Medoff (1989, Table 1, 1b), who report a wage-firm size elasticity of $0.013 \%$ using May CPS wage data. However, not all wages increase with firm size. Indeed, as the remaining columns show, wages in low- and medium-skill job categories (job levels 1 to 5) do not increase with firm size - they are either invariant to firm size or, if anything, slightly decreasing. In contrast, wages in high-skill job categories (job levels 6 to 9 ) increase with firm size. For these wages, the rate of increase is larger for higher job levels, which explains why "top-top" wage ratios, such as 78, 79, or 89, all increase with firm size.

Altogether, our results suggest two things. First, while the employer size-wage effect also holds in our data - wages increase with firm size on average - it is entirely driven by the upper tail of the skill distribution. Second, and more important, the invariance of middle-bottom wage ratios to firm size is not driven by wages in medium- and low-skill job categories both increasing (or decreasing) at the same rate. Rather, wages in both skill categories are individually invariant to firm size. 


\section{Routine and Managerial Job Tasks}

Why do wages in high-skill job categories increase with firm size but not wages in low- and medium-skill job categories? One possible explanation is that there exist countervailing mechanisms putting downward pressure on wages in low- and medium-skill job categories at larger firms, offsetting the general tendency of wages to increase with firm size. ${ }^{9}$ Below we focus on two such mechanisms. The first posits that wages associated with "routine" job tasks are relatively lower in larger firms due to a higher degree of automation in these firms. The second mechanism posits that larger firms pay relatively lower entry-level managerial wages in return for providing better career opportunities.

\subsection{Routine versus Non-Routine Jobs}

In a seminal paper, Autor, Levy, and Murnane (2003, ALM) posit that computer capital substitutes for human skills in carrying out a limited and well-defined set of cognitive and manual activities that can be accomplished by following explicit rules and procedures ("routine tasks"). Such activities are readily automated, because they can be codified in computer sofware and thus performed by machines. On the other hand, computer capital complements "abstract" creative, problem-solving, and coordination activities ("nonroutine tasks"). Drawing on this distinction between routine and non-routine tasks, ALM argue that computerization lowers the wages associated with routine tasks relative to those associated with non-routine tasks.

In a similar vein, Acemoglu and Autor (2011, p. 1138) note that "the set of tasks most subject to machine displacement in the current era are those that are routine or codifiable. Such tasks are primarily, though not exclusively, performed by medium skill (semi-skilled) workers." The authors argue that, under plausible assumptions, the automation of routine job tasks raises the wages of high-skill workers relative to those of medium- and low-skill workers. Importantly, however, the wages of medium-skill workers decline relative to

\footnotetext{
${ }^{9}$ For arguments why wages may increase with firm size, including empirical tests, see, e.g., Brown and Medoff (1989), Oi and Idson (1999), and Troske (1999).
} 
those of low-skill workers. ${ }^{10}$

Automation, whether in manufacturing or services, involves substantial fixed costs. Hence, for CNC machine tools, CAD/CAM systems, robots, or logistics support tools to pay their way, a firm's scale of operations must be sufficiently large. In view of the above discussion, we may therefore hypothesize that wages associated with routine job tasks are relatively lower in larger firms, especially for medium-skill workers. ${ }^{11}$ To investigate this hypothesis, we divide job titles into two groups, routine and non-routine, based on their SOC codes and the classification in ALM. ${ }^{12}$

Specifically, we classify a job title as routine if the ALM routine task intensity measure is above the sample median and the ALM non-routine task intensity measure is below the sample median. Conversely, we classify a job title as non-routine if the ALM routine task intensity measure is below the sample median and the ALM non-routine task intensity measure is above the sample median. Job titles for which this assignment is ambiguousi.e., both task intensity measures are either above or below the sample median - are dropped from the analysis.

Panel A of Table 6 shows the distribution of routine and non-routine jobs for each job level, or skill category. The last column reports their ratio. As can be seen, this ratio follows a hump-shaped pattern, similar to what Autor and Dorn (2013, Figure 4) find. Specifically, it peaks at job level 2, the second lowest skill category, and declines (almost) monotonically thereafter. Indeed, routine jobs are virtually non-existent among higher job levels (7 to 9 ), which is why these job levels are excluded from our subsequent

\footnotetext{
${ }^{10}$ Empirical support for the ALM routinization hypothesis is provided by Autor, Katz, and Kearney (2006, 2008), Goos and Manning (2007), Autor and Dorn (2013), Firpo, Fortin, and Lemieux (2013), Michaels, Natraj, and Van Reenen (2014), and Goos, Manning, and Salomons (2014).

${ }^{11}$ In general, the idea is that larger firms can better amortize the fixed costs associated with technology adoption. If human skills and new technologies are complements, this implies that larger firms should pay relatively higher wages (e.g., Hamermesh (1980), Dunne and Schmitz (1995)). By contrast, in the case of routine job tasks, the presumption is that computer-controlled machinery may substitute for human skills, implying relatively lower wages at larger firms.

${ }^{12}$ The UK Office for National Statistics (ONS) and the US Bureau of Labor Statistics (BLS) provide crosswalks between UK SOC codes, ISCO codes, and US SOC codes. Note that SOC codes do not provide the same information as job levels, or skill categories. For example, UK SOC code 3562, defined as "Human Resources and Industrial Relations Officers," comprises job titles from various skill categories, including Assistant HR/Personnel Officer, HR Junior Manager, Recruitment Officer, Senior Learning and Development Officer, and Recruitment Manager.
} 
regression analysis.

Panel B examines whether wages associated with routine and non-routine jobs vary differently with firm size. All regressions include job-level fixed effects. Thus, the comparison is between routine and non-routine jobs within a given job level, or skill category. Column (1) shows the average effect across all job levels. As can be seen, on average, wages associated with routine jobs decline relative to those associated with non-routine jobs as firm size increases. Column (2) shows that this result is largely driven by jobs in medium-skill categories. Precisely, while the coefficient on the interaction term between firm size and routine jobs is negative for all skill categories, it is strongest - both in magnitude and statistical significance - for job levels 4 and 5. Thus, we may conclude that wages associated with routine jobs are relatively lower in larger firms, especially for jobs in medium-skill categories.

\subsection{Managerial versus Non-Managerial Jobs}

Larger firms provide more opportunities for promotion and career advancement, higher managerial pay at the top (Rosen (1982)), and larger managerial internal labor markets. We may therefore hypothesize that - in return for providing better career opportunities larger firms pay relatively lower entry-level managerial wages. ${ }^{13}$ To investigate this hypothesis, we divide job titles into two groups, managerial and non-managerial, based on their SOC codes and the NS-SEC classification provided by the UK Office for National Statistics (ONS). ${ }^{14}$

Panel A of Table 7 displays the distribution of managerial and non-managerial jobs

\footnotetext{
${ }^{13}$ Tournament models (e.g., Lazear and Rosen (1981)) make similar predictions. In these models, managerial incentives are provided through wage differentials ("prizes") between lower- and higher-level managerial jobs. Larger firms have more contestants and thus require greater wage differentials - i.e., lower entry-level managerial wages and higher top-level managerial wages (McLaughlin (1988)). Similarly, deferred compensation models (e.g., Lazear $(1979,1981)$ ) predict that larger firms pay lower entry-level managerial wages as these firms can more credibly promise to make future wage payments due to their lower bankruptcy risk.

${ }^{14}$ The NS-SEC is an occupation-based classification scheme that is meant to identify the socio-economic position of an employee, with explicit reference to managerial and supervisory occupations. See http://www.ons.gov.uk/ons/guide-method/classifications/current-standardclassifications/soc2010/soc2010-volume-3-ns-sec-rebased-on-soc2010-user-manual/index.html\#15.
} 
for each job level, or skill category. The last column shows their ratio. As can be seen, this ratio is lowest in job level 1 and increases (almost) monotonically thereafter. Indeed, managerial jobs are virtually non-existent in job levels 1 and 2, while non-managerial jobs are non-existent in job level 9. For these reasons, we exclude these job levels from our subsequent regression analysis.

Panel B examines whether wages associated with managerial and non-managerial jobs vary differently with firm size. All regressions include job-level fixed effects. Thus, the comparison is between managerial and non-managerial jobs within a given job level, or skill category. Column (1) shows the average effect across all job levels. As can be seen, managerial and non-managerial wages do not vary differently with firm size on average. Column (2), which offers a breakdown by skill category, shows that this is due to two opposing effects that offset each other. Precisely, while the coefficient on the interaction term between firm size and managerial jobs is negative for low- to medium-skill categories (job levels 3 to 5 ), it is positive for higher-skill categories (job levels 6 to 8 ). Thus, larger firms pay relatively lower entry-level managerial wages but relatively higher top-level managerial wages.

\section{$5 \quad$ Wage Inequality and Firm Growth}

\subsection{Within-Firm Changes in Skill Premia}

In this final part of our firm-level analysis, we explore how skill premia vary within firms over time. As mentioned previously, IDS samples firms multiple times. The average sampling rate is 3.6 times, and the median is 3 times. Therefore, we may focus exclusively on within-firm variation. Table 8 presents the results. To facilitate comparison with trends in aggregate wage data, we group skill premia into three categories: top-bottom wage ratios $(18,28,19$, or 29 ; "overall wage inequality"), top-middle wage ratios (48, 49, 58, or 59; "upper-tail wage inequality"), and middle-bottom wage ratios $(14,15,24,25$, "lower-tail wage inequality"). All regressions include firm, year, and job-level pair fixed

effects. As can be seen, firm growth has a positive effect on top-bottom and top-middle 
wage ratios but no significant effect on middle-bottom wage ratios. Thus, as firms grow larger during the sample period, within-firm wage differentials between high- and either medium- or low-skill jobs increase, while those between medium- and low-skill jobs remain largely unaffected.

Changes in within-firm wage differentials do not necessarily imply changes in aggregate wage differentials. Whether they do depends fundamentally on which firms are driving aggregate wage trends, an issue we revisit below. For now, let us merely say that our results appear to line up well with aggregate wage trends in the UK during the sample period. As Figure 1 shows, upper- and lower-tail wage inequality move in tandem until the late 1990s, when they begin to diverge. Precisely, while upper-tail wage inequality continues to rise, lower-tail wage inequality remains relatively flat. ${ }^{15}$ The US has witnessed a similar polarization of wages, except that it begins a decade earlier (Figure 2). ${ }^{16}$ Our results suggest that both patterns, for the UK and the US, may be related to firm growth. The question, however, is: growth of what firms?

\subsection{Growth of What Firms?}

In the US, as in most countries around the world, the median firm is extremely small. According to the 2011 U.S. Census Bureau's Statistics of U.S. Businesses, the median firm among all (payroll) firms has 0-4 employees. ${ }^{17}$ In fact, $62.1 \%$ of all firms have 04 employees. At the same time, firms with 0-4 employees account for only $5.2 \%$ of all employment. On the other hand, firms with 500+ employees, while constituting only $0.3 \%$ of all firms, account for $51.5 \%$ of all employment. Most of this employment comes from the very largest of firms: those with 10,000+ employees, while constituting only $0.016 \%$ of all firms, account for $27.8 \%$ of all employment.

The above statistics suggest that, when thinking about the relation between wage

\footnotetext{
${ }^{15}$ Figure 1 is from Machin (2010, Figure 11.2). See also Machin and van Reenen (2007).

${ }^{16}$ Figure 2 is from Goldin and Katz (2007, Figure 3). See also Autor, Katz, and Kearney (2006, 2008) and Lemieux (2006, 2008).

${ }^{17}$ If non-payroll firms - "self-employed persons operating unincorporated businesses" - are included, the picture looks even more dramatic. Accordingly, 79.8\% of all firms in 2011 are non-payroll firms.
} 
inequality and firm growth, one should not be thinking about the median firm. The median firm in the US had 0-4 employees in 1992 and still has 0-4 employees today. Moreover, all of the theoretical arguments discussed in Section 4 apply to larger firms. Indeed, the average firm in our sample of UK firms has 10,014 employees. Thus, our results do not apply to small firms with only a few employees.

Among larger firms, there has been substantial growth. Between 1980 and 2011, the average firm size (in market values) among the largest 500 firms in the US has grown by $425 \%$ (Gabaix, Landier, and Sauvagnat (2014)). Perhaps more informative for our purposes are changes in employment. According to the U.S. Census Bureau's Statistics of U.S. Businesses, firms with $500+$ employees account for $45.5 \%$ of all employment in 1988. By 2011, this number has risen to $51.5 \%$, an increase of $13.2 \%$ in 23 years. Thus, the median employee in the US today works for a firm with 500+ employees.

A similar picture emerges when looking at the average employment (instead of the employment share) of large firms. As is shown in Table 9 below, between 1986 and 2010, average employment by the 50 (100) largest firms in the US has risen by $55.8 \%$ (53.0\%). The numbers are similar for the UK, where average employment by the 50 (100) largest firms has risen by $51.3 \%$ (43.5\%). More generally, the table shows that over the past decades, average employment by large firms has risen for a broad set of developed countries. As we show next, for these countries, firm growth is positively related to rising wage inequality — even after accounting for common time trends.

\subsection{Wage Inequality and Firm Growth in Developed Countries}

Besides the UK and the US, few other developed countries exhibit wage polarization (Naticchioni, Ragusa, and Massari (2014)). This is somewhat puzzling, as most of these countries exhibit employment polarization, which is essentially the "quantity counterpart" to wage polarization. ${ }^{18,19}$ Naturally, we would not expect our "more granular" results,

\footnotetext{
${ }^{18}$ Autor (2014b) provides arguments for why employment polarization may not necessarily result in wage polarization.

${ }^{19}$ Empirical evidence of employment polarization is provided by Goos and Manning (2007, UK), Autor, Katz, and Kearney (2006, 2008, US), Michaels, Natraj, and Van Reenen (2014, 11 developed countries), and Goos, Manning, and Salomons (2009, 2014, 16 European countries).
} 
especially those distinguishing between upper- and lower-tail wage inequality, to hold in countries where wage polarization does not exist in the first place. However, on a less granular level, our firm-level results suggest a relation between firm growth and overall wage inequality, where the latter has risen in many, if not most, developed countries (e.g., Machin and van Reenen (2007, Table 2), Machin (2010, Table 11.2), OECD (2011, Table A1.1)). Thus, we may examine whether firm growth and overall wage inequality are related at the country level.

Our wage data are from LIS, formerly known as The Luxembourg Income Study. LIS is a non-profit organization dedicated to collecting and distributing data for research purposes and advertises as having the largest collection of harmonized micro data for a broad set of countries and years. LIS data are particularly well suited for our purposes, as they use official data collected from individual countries' statistical offices. ${ }^{20}$ The data include labor income for a broad cross-section of employees in a given country and year. We limit our sample to full-time employees by excluding employees identified as part-time and those that report working less than 35 hours per week. Using the sample of all fulltime employees in a given country and year, we estimate the 10th and 90th percentiles of the respective wage distribution. Our measure of overall wage inequality is the $\log 90 / 10$ wage differential. LIS data are not available for every year and, for most countries, there is a gap of several years between surveys. On average, we have wage distribution data for six different years for the countries in our sample.

We source firm size data from Thomson Reuters Worldscope. Worldscope provides data on firm fundamentals for publicly listed firms in a broad set of countries. As discussed in Section 5.2, the relationship between wage inequality and firm growth is likely driven by larger firms. Accordingly, we calculate the average number of employees for either the 50 or 100 largest firms in a given country and year. (If there are fewer than 100 firms with available employment data in a given country and year, that country-year observation is dropped from the top 100 sample.) As is shown in Appendix Table A5, all results are

\footnotetext{
${ }^{20}$ LIS data have been previously used in cross-country studies of wage inequality by Gottschalk and Smeeding (1997) and Acemoglu (2003), among others. To further verifiy that LIS data are suitable for our purposes, we have recreated Figures 1 (UK) and 2 (US) and obtained similar results.
} 
similar if we use the median number of employees of the 50 (100) largest firms in lieu of the average number of employees.

Our final sample consists of all countries for which we have both wage data and firmsize data: Australia, Austria, Belgium, Canada, Denmark, Finland, France, Germany, Greece, Italy, Netherlands, Spain, Sweden, United Kingdom, and United States. The earliest year in our sample is 1981, and the latest year is 2010. Table 9 shows for each country the first and last year in the sample, number of country-year observations, and change in average employment among the 50 (100) largest firms in the country between the first and last sample year. As can be seen, firm growth is pervasive during the sample period. With the exception of Denmark, the change in average employment among the top 50 (100) firms is positive in all countries. Also, as mentioned before, large firms have similar growth rates in the UK and the US.

Table 10 examines the relation between wage inequality, expressed through the log 90/10 wage differential, and the average number of employees (in logs) of the 50 (100) largest firms in a given country and year. The regressions in columns (1) and (4) include both country and year fixed effects. Those in columns (2)-(3) and (5)-(6) include country fixed effects but no year fixed effects. Instead, they include a linear time trend defined as the given year minus 1999. Two results stand out. First, and importantly, there is a positive and significant relation between rising wage inequality and employment growth by the largest firms in the economy. Second, adding firm size to the regression reduces the magnitude of the coefficient on the common time trend by $36.1 \%$ and $39.8 \%$, respectively. Thus, part of what may be perceived as a global trend toward more wage inequality may be actually coming from an increase in employment by the largest firms in the economy.

\section{Conclusion}

We examine how within-firm skill premia - wage differentials associated with jobs involving different skill requirements — vary both across firms and over time. Our results mirror patterns found in aggregate wage trends, except that we find them with regard to increases in firm size. In particular, we find that wage differentials between high- and either 
medium- or low-skill jobs increase with firm size, while those between medium- and lowskill jobs are largely invariant to firm size. We find the same pattern within firms over time, suggesting that rising wage inequality - even nuanced patterns, such as divergent trends in upper- and lower-tail inequality - may be related to firm growth. To explore this hypothesis more generally, we consider a broad set of developed countries focusing on the 50 or 100 largest firms per country. We find evidence of strong firm growth among large firms in practically all of these countries. More importantly, we find that within-country variation in firm growth is positively and significantly related to rising wage inequality, even after accounting for common time trends.

Altogether, our results suggest that firm growth, especially of large firms, may contribute to rising wage inequality in two ways. First, it may act as a catalyst for already existing explanations that, as such, are not necessarily linked to firm growth. For instance, explanations for the divergent trends in upper- and lower-tail wage inequality based on the automation of routine job tasks (e.g., Autor, Katz, and Kearney (2006), Acemoglu and Autor (2011)) do not require firm growth. However, if larger firms are more likely to automate routine job tasks, then firm growth may act as a catalyst for task-replacing technological change (Section 4.1). Second, firm growth may contribute to rising wage inequality through channels that are inherently linked to firm size. For instance, if larger firms exhibit wider spreads between top- and entry-level wages, then firm growth may directly contribute to rising wage inequality through this channel (Section 4.2). Clearly,

these are only two of several possible mechanisms through which firm growth may affect wage inequality. Exploring these and other mechanisms in more detail constitutes a fruitful area for future research.

\section{References}

Acemoglu, Daron, 2002, Technical Change, Inequality, and the Labor Market, Journal of Economic Literature 40, 7-72.

Acemoglu, Daron, 2003, Cross-Country Inequality Trends, Economic Journal 113, F121- 
F149.

Acemoglu, Daron, and David Autor, 2011, Skills, Tasks and Technologies: Implications for Employment and Earnings, in: Handbook of Labor Economics, Volume 4, Chapter 12, Orley Ashenfelter and David Card (eds.), 1043-1171, Amsterdam: North-Holland.

Acemoglu, Daron, and Fabrizio Zilibotti, 2001, Productivity Differences, Quarterly Journal of Economics 116, 563-606.

Autor, David, 2014a, Skills, Education, and the Rise of Earnings Inequality Among the "Other 99 Percent," Science 344, 843-851.

Autor, David, 2014b, Polanyi's Paradox and the Shape of Employment Growth, mimeo, MIT.

Autor, David, and David Dorn, 2013, The Growth of Low-Skill Service Jobs and the Polarization of the US Labor Market, American Economic Review 103, 1553-1597.

Autor, David, Lawrence Katz, and Melissa Kearney, 2006, The Polarization of the U.S. Labor Market, American Economic Review Papers and Proceedings 96, 189-194.

Autor, David, Lawrence Katz, and Melissa Kearney, 2008, Trends in U.S. Wage Inequality: Revising the Revisionists, Review of Economics and Statistics 90, 300-323.

Autor, David, Lawrence Katz, and Alan Krueger, 1998, Computing Inequality: Have Computers Changed the Labor Market? Quarterly Journal of Economics 113, 11691213.

Autor, David, Frank Levy, and Richard Murnane, 2003, The Skill Content of Recent Technological Change: An Empirical Exploration, Quarterly Journal of Economics 118, 1279-1333.

Brown, Charles, and James Medoff, 1989, The Employer Size-Wage Effect, Journal of Political Economy 97, 1027-1059. 
Card, David, and Thomas Lemieux, 2001, Can Falling Supply Explain the Rising Return to College for Younger Men? A Cohort-Based Analysis, Quarterly Journal of Economics 116, 705-746.

Costinot, Arnaud, and Jonathan Vogel, 2010, Matching and Inequality in a World Economy, Journal of Political Economy 118, 747-786.

Dunne, Timothy, and James Schmitz, Jr.,1995, Wages, Employment Structure and Employer Size-Wage Premia: Their Relationship to Advanced-Technology Usage at US Manufacturing Establishments, Economica 62, 89-107.

Firpo, Sergio, Nicole Fortin, and Thomas Lemieux, 2013, Occupational Tasks and Changes in the Wage Structure, mimeo, University of British Columbia.

Gabaix, Xavier, Augustin Landier, and Julien Sauvagnat, 2014, CEO Pay and Firm Size: An Update After the Crisis, Economic Journal 124, F40-F59.

Goldin, Claudia, and Lawrence Katz, 2007, Long-Run Changes in the Wage Structure: Narrowing, Widening, Polarizing, Brookings Papers on Economic Activity, 135-165.

Goos, Maarten, and Alan Manning, 2007, Lousy and Lovely Jobs: the Rising Polarization of Work in Britain, The Review of Economics and Statistics 89, 118-133.

Goos, Maarten, Alan Manning, and Anna Salomons, 2009, Job Polarization in Europe, American Economic Review Papers and Proceedings 99, 58-63.

Goos, Maarten, Alan Manning, and Anna Salomons, 2014, Explaining Job Polarization: Routine-Biased Technological Change and Offshoring, American Economic Review 104, 2509-2526.

Gottschalk, Peter, and Timothy Smeeding, 1997, Cross-National Comparisons of Earnings and Income Inequality, Journal of Economic Literature 35, 633-687.

Hamermesh, Daniel, 1993, Labor Demand, Princeton, NJ: Princeton University Press. 
Katz, Lawrence, and Kevin Murphy, 1992, Changes in Relative Wages, 1963-1987: Supply and Demand Factors, Quarterly Journal of Economics 107, 35-78.

Lazear, Edward, 1979, Why Is There Mandatory Retirement?, Journal of Political Economy $87,1261-1284$.

Lazear, Edward, 1981, Agency, Earnings Profiles, Productivity, and Hours Restrictions, American Economic Review 71, 606-620.

Lazear, Edward, and Sherwin Rosen, 1981, Rank-Order Tournaments as Optimum Labor Contracts, Journal of Political Economy 89, 841-864.

Lemieux, Thomas, 2006, Increasing Residual Wage Inequality: Composition Effects, Noisy Data, or Rising Demand for Skill? American Economic Review 96, 461-498.

Lemieux, Thomas, 2008, The Changing Nature of Wage Inequality, Journal of Population Economics 21, 21-48.

Luxembourg Income Study Database (LIS), www.lisdatacenter.org (multiple countries; $\{2014\})$. Luxembourg: LIS.

Machin, Stephen, 2010, Changes in UK Wage Inequality Over the Last Forty Years, in: The Labour Market in Winter: The State of Working Britain, Paul Gregg and Jonathan Wadsworth (eds.), 155-169, Oxford: Oxford University Press.

Machin, Stephen, and John Van Reenen, 2007, Changes in Wage Inequality, Special Paper No.18, Centre for Economic Performance, LSE.

McLaughlin, Kenneth, 1988, Aspects of Tournament Models: A Survey, in: Research in Labor Economics, Volume 9, Ronald Ehrenberg (ed.), 225-256, Greenwich, CT: JAI.

Michaels, Guy, Ashwini Natraj, and John Van Reenen, 2014, Has ICT Polarized Skill Demand? Evidence from Eleven Countries over 25 years, The Review of Economics and Statistics 96, 60-77. 
Naticchioni, Paolo, Giuseppe Ragusa, and Riccardo Massari, 2014, Unconditional and Conditional Wage Polarization in Europe, IZA DP No. 8465.

Oi, Walter, and Todd Idson, 1999, Firm Size and Wages, in: Handbook of Labor Economics, Volume 3, Orley Ashenfelter and David Card (eds.), 2165-2214, Amsterdam: North-Holland.

OECD, 2011, Divided We Stand: Why Inequality Keeps Rising, OECD Publishing.

Rosen, Sherwin, 1982, Authority, Control and the Distribution of Earnings, Bell Journal of Economics 13, 311-323.

Tinbergen, Jan, 1974, Substitution of Graduate by Other Labor, Kyklos 27, 217-226.

Tinbergen, Jan, 1975, Income Differences: Recent Research, Amsterdam: North Holland.

Troske, Kenneth, 1999, Evidence on the Employer-Size Wage Premium from WorkerEstablishment Matched Data, Review of Economics and Statistics 81, 15-26. 


\section{Table 1 \\ Job Levels / Skill Categories}

Job Level Examples of Job Titles

1

Cleaner, Labourer, Unskilled Worker

2

Administrative Assistant, Driver, Operator

3

Technician, Craftsman, Skilled Worker

4

Craftsman - Multiskilled, HR/Personnel Officer, Retail Manager

Engineer, Marketing Junior Manager, Warehouse Supervisor

Engineering Manager, Lawyer Senior, Operations Manager

Finance Function Head, IT Function Head, Sales Function Head
Area Sales/Account Manager, Engineer - Senior, Manager - Middle
Finance Director, HR Director,

Lawyer - Head of Legal

\author{
IDS Description
}

Work requires basic literacy and numeracy skills and the ability to perform a few straightforward and short-term tasks to instructions under immediate supervision. Previous experience is not necessary (IDS Job Level 1). Work requires developed literacy and numeracy skills and the ability to perform some routine tasks within procedures that may include keyboard and practical skills and initial contact with customers. Some previous experience is required (IDS Job Level 2).

Work requires specific administrative, practical, craft or technical skills gained by previous experience and qualifications to carry out a range of less routine work and to provide specialist support, and could include closer contact with the public/customers (IDS Job Level 3).

Work requires broad and deep administrative, technical or craft skills and experience to carry out a wider range of activities including staff supervision, undertaking specialist routines and procedures and providing some advice (IDS Job Level 4).

Work requires detailed experience and possibly some level of vocational qualification to be able to oversee the operation of an important procedure or to provide specialist advice and services, involving applied knowledge of internal systems and procedures (IDS Job Level 5).

Work requires a vocational qualification and sufficient relevant specialist experience to be able to manage a section or operate with self-contained expertise in a specialist discipline or activity (IDS Job Level 6).

Work is concerned with the provision of professional services and requires an experienced and qualified professional to provide expertise and advice and operate independently. Also includes operational managers responsible for service delivery (IDS Job Level 7).

Work requires deep professional experience and qualifications in a specific discipline to be able to carry out a range of specialist technical or scientific activities, which may include the management of a team or services. May also include specialist management roles responsible for delivery of a major service (IDS Job Level 8).

Senior managerial roles involved in managing an important activity or providing authoritative expertise, also contributing to the organisation as a whole through significant experience (IDS Job Level 9).

Very senior executive roles with substantial experience in, and leadership of, a specialist function, including some input to the organisation's overall strategy (IDS Job Level 10). 


\section{Table 2}

Wages per Job Level

This table shows the distribution of wages for each job level, or skill category, across all firm-year observations. Wages are in GBP. Job levels are described in Table 1. The sample period is from 2004 to 2013.

\begin{tabular}{cccccc}
\hline Job Level & Obs. & Avg. Wage & $\mathbf{2 5 \%}$ & $\mathbf{5 0 \%}$ & $\mathbf{7 5 \%}$ \\
\hline \hline 1 & 696 & 13,778 & 11,090 & 13,413 & 16,001 \\
2 & 890 & 16,248 & 13,122 & 16,354 & 18,731 \\
3 & 852 & 19,621 & 16,471 & 19,715 & 22,371 \\
4 & 1,034 & 22,815 & 19,662 & 22,562 & 25,344 \\
5 & 955 & 29,352 & 24,783 & 28,496 & 32,901 \\
6 & 868 & 38,878 & 31,961 & 36,806 & 43,330 \\
7 & 696 & 52,977 & 40,632 & 48,793 & 60,587 \\
8 & 461 & 85,014 & 57,967 & 74,236 & 100,813 \\
9 & 240 & 110,693 & 77,844 & 101,494 & 131,004 \\
\hline
\end{tabular}


Table 3

Wage Ratios / Skill Premia

This table shows the distribution of wage ratios, or skill premia, for all 36 job-level pairs. Wage ratios are computed by dividing the wage associated with the higher job level by the wage associated with the lower job level when both wages are observed in the same firm and year. Job levels are described in Table 1. Ratio $>1(\%)$ denotes the percentage of firm-year observations for which the wage ratio exceeds one. The sample period is from 2004 to 2013.

\begin{tabular}{|c|c|c|c|c|c|c|}
\hline Job-Level Pair & Obs. & Avg. Wage Ratio & $25 \%$ & $50 \%$ & $75 \%$ & Ratio > $1(\%)$ \\
\hline 12 & 559 & 1.171 & 1.083 & 1.154 & 1.234 & 96 \\
\hline 13 & 474 & 1.364 & 1.217 & 1.332 & 1.474 & 98 \\
\hline 14 & 449 & 1.635 & 1.371 & 1.579 & 1.791 & 100 \\
\hline 15 & 383 & 1.959 & 1.620 & 1.875 & 2.204 & 100 \\
\hline 16 & 295 & 2.517 & 1.964 & 2.342 & 2.928 & 100 \\
\hline 17 & 193 & 3.376 & 2.500 & 3.084 & 3.954 & 100 \\
\hline 18 & 74 & 5.920 & 3.616 & 4.742 & 6.817 & 100 \\
\hline 19 & 23 & 8.286 & 4.798 & 7.429 & 9.820 & 100 \\
\hline 23 & 660 & 1.208 & 1.108 & 1.173 & 1.281 & 95 \\
\hline 24 & 597 & 1.417 & 1.222 & 1.365 & 1.548 & 97 \\
\hline 25 & 511 & 1.728 & 1.430 & 1.652 & 1.907 & 99 \\
\hline 26 & 415 & 2.225 & 1.814 & 2.122 & 2.506 & 100 \\
\hline 27 & 251 & 2.899 & 2.208 & 2.683 & 3.364 & 100 \\
\hline 28 & 99 & 4.981 & 2.986 & 3.962 & 6.006 & 100 \\
\hline 29 & 36 & 7.301 & 5.064 & 6.379 & 9.383 & 100 \\
\hline 34 & 631 & 1.208 & 1.083 & 1.177 & 1.292 & 90 \\
\hline 35 & 542 & 1.496 & 1.264 & 1.428 & 1.634 & 98 \\
\hline 36 & 436 & 1.928 & 1.582 & 1.853 & 2.190 & 100 \\
\hline 37 & 275 & 2.507 & 1.909 & 2.260 & 2.904 & 100 \\
\hline 38 & 109 & 4.384 & 2.600 & 3.472 & 5.310 & 100 \\
\hline 39 & 46 & 6.515 & 4.212 & 5.735 & 8.670 & 100 \\
\hline 45 & 648 & 1.295 & 1.129 & 1.249 & 1.406 & 94 \\
\hline 46 & 542 & 1.655 & 1.383 & 1.575 & 1.846 & 99 \\
\hline 47 & 399 & 2.230 & 1.755 & 2.090 & 2.551 & 100 \\
\hline 48 & 202 & 3.547 & 2.493 & 3.237 & 4.157 & 100 \\
\hline 49 & 112 & 5.442 & 3.979 & 4.970 & 6.398 & 100 \\
\hline
\end{tabular}


Table 3 (continued)

\begin{tabular}{ccccccc}
\hline Job-Level Pair & Obs. & Avg. Wage Ratio & $\mathbf{2 5 \%}$ & $\mathbf{5 0 \%}$ & $\mathbf{7 5 \%}$ & Ratio $\mathbf{~} \mathbf{~ ( \% ) ~}$ \\
\hline \hline 56 & 693 & 1.315 & 1.161 & 1.278 & 1.429 & 94 \\
57 & 557 & 1.770 & 1.497 & 1.702 & 1.975 & 99 \\
58 & 346 & 2.720 & 2.059 & 2.463 & 3.055 & 100 \\
59 & 193 & 3.826 & 2.837 & 3.641 & 4.534 & 100 \\
& & & & & \\
67 & 576 & 1.362 & 1.220 & 1.338 & 1.468 & 96 \\
68 & 391 & 2.013 & 1.598 & 1.875 & 2.209 & 100 \\
69 & 214 & 2.806 & 2.088 & 2.685 & 3.296 & 100 \\
78 & & & & & \\
79 & 397 & 1.480 & 1.240 & 1.391 & 1.601 & 98 \\
89 & 213 & 2.121 & 1.700 & 1.981 & 2.391 & 100 \\
\hline
\end{tabular}




\section{Table 4}

\section{Skill Premia and Firm Size}

The dependent variable is the skill premium, or wage ratio (in logs), associated with a given job-level pair. Firm size is measured as the number of employees (in logs). All regressions include year fixed effects. Standard errors (in parentheses) are clustered at the firm level. The sample period is from 2004 to 2013. *, **, and *** denotes significance at the $10 \%, 5 \%$, and $1 \%$ level, respectively.

Panel (A):

\begin{tabular}{|c|c|c|c|c|c|c|c|c|}
\hline Job-Level Pair & 12 & 13 & 14 & 15 & 16 & 17 & 18 & 19 \\
\hline lg_empl & $\begin{array}{l}-0.00117 \\
(0.00345)\end{array}$ & $\begin{array}{l}-0.00462 \\
(0.00506)\end{array}$ & $\begin{array}{c}0.00791 \\
(0.00656)\end{array}$ & $\begin{array}{c}0.00896 \\
(0.00926)\end{array}$ & $\begin{array}{c}0.0375 * * * \\
(0.0115)\end{array}$ & $\begin{array}{c}0.0883 * * * \\
(0.0152)\end{array}$ & $\begin{array}{c}0.162 * * * \\
(0.0259)\end{array}$ & $\begin{array}{c}0.179 * * * \\
(0.0392)\end{array}$ \\
\hline Constant & $\begin{array}{c}0.171 * * * \\
(0.0296)\end{array}$ & $\begin{array}{c}0.373 * * * \\
(0.0489)\end{array}$ & $\begin{array}{c}0.462 * * * \\
(0.0664)\end{array}$ & $\begin{array}{c}0.626 * * * \\
(0.0932)\end{array}$ & $\begin{array}{c}0.568 * * * \\
(0.133)\end{array}$ & $\begin{array}{c}0.445 * * \\
(0.213)\end{array}$ & $\begin{array}{l}-0.232 \\
(0.195)\end{array}$ & $\begin{array}{c}0.372 \\
(0.252)\end{array}$ \\
\hline Observations & 559 & 474 & 449 & 383 & 295 & 193 & 74 & 23 \\
\hline R-squared & 0.024 & 0.040 & 0.070 & 0.050 & 0.147 & 0.377 & 0.505 & 0.740 \\
\hline
\end{tabular}

Panel (B):

\begin{tabular}{|c|c|c|c|c|c|c|c|}
\hline Job-Level Pair & 23 & 24 & 25 & 26 & 27 & 28 & 29 \\
\hline lg_empl & $\begin{array}{c}-0.0109 * * * \\
(0.00370)\end{array}$ & $\begin{array}{l}-0.00493 \\
(0.00545)\end{array}$ & $\begin{array}{l}-0.00905 \\
(0.00659)\end{array}$ & $\begin{array}{c}0.00584 \\
(0.00883)\end{array}$ & $\begin{array}{c}0.0605^{* * *} \\
(0.0115)\end{array}$ & $\begin{array}{c}0.133^{* * *} \\
(0.0256)\end{array}$ & $\begin{array}{c}0.152 * * * \\
(0.0382)\end{array}$ \\
\hline Constant & $\begin{array}{c}0.268 * * * \\
(0.0337)\end{array}$ & $\begin{array}{c}0.391 * * * \\
(0.0511)\end{array}$ & $\begin{array}{c}0.632 * * * \\
(0.0675)\end{array}$ & $\begin{array}{c}0.662 * * * \\
(0.0826)\end{array}$ & $\begin{array}{c}0.482 * * * \\
(0.123)\end{array}$ & $\begin{array}{c}0.198 \\
(0.196)\end{array}$ & $\begin{array}{c}0.714^{* *} \\
(0.326)\end{array}$ \\
\hline Observations & 660 & 597 & 511 & 415 & 251 & 99 & 36 \\
\hline R-squared & 0.037 & 0.029 & 0.061 & 0.027 & 0.209 & 0.398 & 0.361 \\
\hline
\end{tabular}

Panel (C):

\begin{tabular}{|c|c|c|c|c|c|c|}
\hline Job-Level Pair & 34 & 35 & 36 & 37 & 38 & 39 \\
\hline lg_empl & $\begin{array}{c}0.00412 \\
(0.00534)\end{array}$ & $\begin{array}{c}0.00712 \\
(0.00750)\end{array}$ & $\begin{array}{l}0.0187 * \\
(0.0103)\end{array}$ & $\begin{array}{c}0.0717 * * * \\
(0.0152)\end{array}$ & $\begin{array}{c}0.147 * * * \\
(0.0292)\end{array}$ & $\begin{array}{c}0.159 * * * \\
(0.0370)\end{array}$ \\
\hline Constant & $\begin{array}{c}0.147^{* * *} \\
(0.0445)\end{array}$ & $\begin{array}{c}0.320 * * * \\
(0.0671)\end{array}$ & $\begin{array}{c}0.396 * * * \\
(0.0850)\end{array}$ & $\begin{array}{c}0.246 \\
(0.154)\end{array}$ & $\begin{array}{c}0.476 * * * \\
(0.166)\end{array}$ & $\begin{array}{c}0.247 \\
(0.284)\end{array}$ \\
\hline Observations & 631 & 542 & 436 & 275 & 109 & 46 \\
\hline R-squared & 0.024 & 0.027 & 0.044 & 0.239 & 0.347 & 0.407 \\
\hline
\end{tabular}

Panel (D):

\begin{tabular}{lccccc}
\hline Job-Level Pair & $\mathbf{4 5}$ & $\mathbf{4 6}$ & $\mathbf{4 7}$ & $\mathbf{4 8}$ & $\mathbf{4 9}$ \\
\hline \hline lg_empl & -0.000639 & $0.0205^{* * *}$ & $0.0566^{* * *}$ & $0.105^{* * *}$ & $0.102^{* * *}$ \\
& $(0.00429)$ & $(0.00660)$ & $(0.00791)$ & $(0.0126)$ & $(0.0188)$ \\
Constant & $0.207^{* * *}$ & $0.271^{* * *}$ & 0.147 & $0.330^{* * *}$ & $0.888^{* * *}$ \\
& $(0.0423)$ & $(0.0569)$ & $(0.0940)$ & $(0.0718)$ & $(0.257)$ \\
& & & & & \\
Observations & 648 & 542 & 399 & 202 & 112 \\
R-squared & 0.023 & 0.061 & 0.195 & 0.323 & 0.266 \\
\hline
\end{tabular}


Table 4 (continued)

Panel (E):

\begin{tabular}{lcccc}
\hline Job-Level Pair & $\mathbf{5 6}$ & $\mathbf{5 7}$ & $\mathbf{5 8}$ & $\mathbf{5 9}$ \\
\hline \hline lg_empl & $0.0201^{* * *}$ & $0.0413^{* * *}$ & $0.0887^{* * *}$ & $0.0914^{* * *}$ \\
& $(0.00450)$ & $(0.00617)$ & $(0.0111)$ & $(0.0132)$ \\
Constant & $0.0874^{*}$ & 0.0916 & $0.276^{* * *}$ & $0.742^{* * *}$ \\
& $(0.0472)$ & $(0.0702)$ & $(0.0630)$ & $(0.143)$ \\
Observations & 693 & 557 & 346 & 193 \\
R-squared & 0.071 & 0.160 & 0.272 & 0.221 \\
\hline
\end{tabular}

Panel (F):

\begin{tabular}{lccc}
\hline Job-Level Pair & $\mathbf{6 7}$ & $\mathbf{6 8}$ & $\mathbf{6 9}$ \\
\hline \hline lg_empl & $0.0176^{* * *}$ & $0.0559^{* * *}$ & $0.0618^{* * *}$ \\
& $(0.00426)$ & $(0.00928)$ & $(0.0124)$ \\
Constant & 0.0493 & $0.119^{* *}$ & $0.602^{* * *}$ \\
& $(0.0405)$ & $(0.0529)$ & $(0.137)$ \\
Observations & 576 & 391 & 214 \\
R-squared & 0.059 & 0.166 & 0.131 \\
\hline
\end{tabular}

Panel (G):

\begin{tabular}{lcc}
\hline Job-Level Pair & $\mathbf{7 8}$ & $\mathbf{7 9}$ \\
\hline \hline lg_empl & $\begin{array}{c}0.0326 * * * \\
(0.00822)\end{array}$ & $\begin{array}{c}0.0457^{* * *} \\
(0.0103)\end{array}$ \\
& 0.0310 & $0.361^{* * *}$ \\
Constant & $(0.0468)$ & $(0.0790)$ \\
& 397 & 213 \\
Observations & 0.101 & 0.106 \\
R-squared & &
\end{tabular}

Panel (H):

\begin{tabular}{lc}
\hline Job-Level Pair & $\mathbf{8 9}$ \\
\hline \hline lg_empl & $\begin{array}{c}0.0244 * * * \\
(0.00875)\end{array}$ \\
& $\begin{array}{c}0.272 * * * \\
(0.0923)\end{array}$ \\
Constant & 201 \\
& 0.050 \\
Observations & \\
R-squared
\end{tabular}


Table 5

The Employer Size-Wage Effect Revisited

The dependent variable is the wage (in logs) associated with a given job level, or skill category. Firm size is measured as the number of employees (in logs). All regressions include year fixed effects. The regression in column "All" additionally includes job-level fixed effects. Standard errors (in parentheses) are clustered at the firm level. The sample period is from 2004 to $2013 .{ }^{*},{ }^{* *}$, and ${ }^{* * *}$ denotes significance at the $10 \%, 5 \%$, and $1 \%$ level, respectively.

\begin{tabular}{lccccc}
\hline Job Level & All & $\mathbf{1}$ & $\mathbf{2}$ & $\mathbf{3}$ & $\mathbf{4}$ \\
\hline \hline lg_empl & $0.0126^{* * *}$ & $-0.0208^{* * *}$ & -0.00631 & -0.0110 & 0.00115 \\
& $(0.00460)$ & $(0.00614)$ & $(0.00704)$ & $(0.00698)$ & $(0.00505)$ \\
Constant & $4.789^{* * *}$ & $5.020^{* * *}$ & $5.123^{* * *}$ & $5.361^{* * *}$ & $5.470^{* * *}$ \\
& $(0.0364)$ & $(0.0525)$ & $(0.0560)$ & $(0.0545)$ & $(0.0431)$ \\
Observations & 6,692 & 696 & 890 & 852 & 1034 \\
R-squared & 0.825 & 0.079 & 0.013 & 0.036 & 0.027 \\
\hline & & & & & \\
\hline Job Level & $\mathbf{5}$ & $\mathbf{6}$ & $\mathbf{7}$ & $\mathbf{8}$ & $\mathbf{9}$ \\
\hline \hline \multirow{2}{*}{ lg_empl } & 0.000350 & $0.0262^{* * *}$ & $0.0535^{* * *}$ & $0.0884^{* * *}$ & $0.104^{* * *}$ \\
& $(0.00628)$ & $(0.00559)$ & $(0.00714)$ & $(0.0132)$ & $(0.0143)$ \\
Constant & $5.631^{* * *}$ & $5.656^{* * *}$ & $5.701^{* * *}$ & $6.001^{* * *}$ & $6.089^{* * *}$ \\
& $(0.0493)$ & $(0.0498)$ & $(0.0889)$ & $(0.0750)$ & $(0.110)$ \\
Observations & 955 & 868 & 696 & 461 & 240 \\
R-squared & 0.041 & 0.061 & 0.151 & 0.223 & 0.227 \\
\hline
\end{tabular}




\section{Table 6 \\ Routine versus Non-Routine Jobs}

Panel (A) shows the distribution of routine and non-routine jobs for each job level, or skill category. In Panel (B), the dependent variable is the wage (in logs) associated with a given job level/routine (job level/non-routine) pair. Firm size is measured as the number of employees (in logs). Routine is a dummy variable that equals one when a job title is classified as routine as described in Section 4.1. The sample in Panel (B) is comprised of job levels 1 to 6. All regressions include year and job-level fixed effects. Standard errors (in parentheses) are clustered at the firm level. The sample period is from 2004 to $2013 .{ }^{*},{ }^{* *}$, and ${ }^{* * *}$ denotes significance at the $10 \%, 5 \%$, and $1 \%$ level, respectively.

\section{Panel (A):}

\begin{tabular}{cccc}
\hline Job Level & Non-Routine & Routine & $\begin{array}{c}\text { Routine/ Non- } \\
\text { Routine }\end{array}$ \\
\hline \hline 1 & 35 & 193 & 5.514 \\
2 & 32 & 379 & 11.844 \\
3 & 74 & 290 & 3.919 \\
4 & 213 & 177 & 0.831 \\
5 & 416 & 61 & 0.147 \\
6 & 363 & 81 & 0.223 \\
7 & 414 & 19 & 0.046 \\
8 & 204 & 0 & 0.000 \\
9 & 163 & 0 & 0.000 \\
\hline
\end{tabular}

Panel (B):

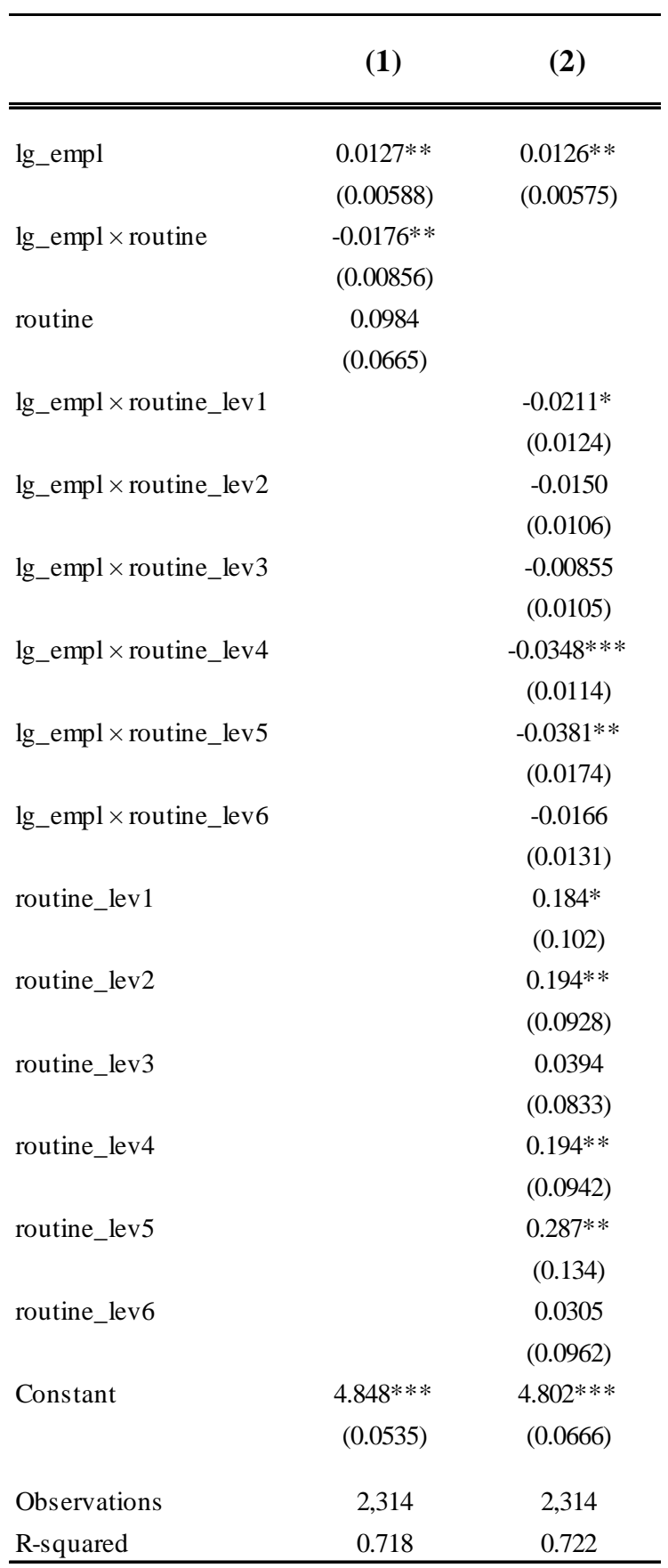




\section{Table 7 \\ Managerial versus Non-Managerial Jobs}

Panel (A) shows the distribution of managerial and non-managerial jobs for each job level, or skill category. In Panel (B), the dependent variable is the wage (in logs) associated with a given job level/managerial (job level/nonmanagerial) pair. Firm size is measured as the number of employees (in logs). Managerial is a dummy variable that equals one when a job title is classified as managerial as described in Section 4.2. All regressions include year and joblevel fixed effects. The sample in Panel (B) is comprised of job levels 3 to 8. Standard errors (in parentheses) are clustered at the firm level. The sample period is from 2004 to 2013. *, **, and *** denotes significance at the 10\%, 5\%, and $1 \%$ level, respectively.

Panel (A):

\begin{tabular}{cccc}
\hline Job Level & Non-Managerial & Managerial & $\begin{array}{c}\text { Managerial/ } \\
\text { Non-Managerial }\end{array}$ \\
\hline \hline 1 & 398 & 3 & 0.0075 \\
2 & 565 & 19 & 0.0336 \\
3 & 456 & 70 & 0.1535 \\
4 & 429 & 71 & 0.1655 \\
5 & 515 & 228 & 0.4427 \\
6 & 345 & 354 & 1.0261 \\
7 & 217 & 393 & 1.8111 \\
8 & 50 & 202 & 4.0400 \\
9 & 0 & 168 & ND \\
\hline
\end{tabular}

Panel (B):

(1)

(2)

\begin{tabular}{|c|c|c|}
\hline \multirow[t]{2}{*}{ lg_empl } & $0.00819 *$ & 0.00802 \\
\hline & $(0.00497)$ & $(0.00498)$ \\
\hline \multirow[t]{2}{*}{ lg_empl × managerial } & 0.00877 & \\
\hline & $(0.00813)$ & \\
\hline \multirow[t]{2}{*}{ managerial } & -0.0525 & \\
\hline & $(0.0606)$ & \\
\hline \multirow[t]{2}{*}{ lg_empl × managerial_lev3 } & & -0.00556 \\
\hline & & $(0.0287)$ \\
\hline \multirow[t]{2}{*}{ lg_empl × managerial_lev4 } & & $-0.0637^{*}$ \\
\hline & & $(0.0357)$ \\
\hline \multirow[t]{2}{*}{ lg_empl × managerial_lev5 } & & $-0.0465 * * *$ \\
\hline & & $(0.0176)$ \\
\hline \multirow[t]{2}{*}{ lg_empl × managerial_lev6 } & & 0.00562 \\
\hline & & $(0.00950)$ \\
\hline \multirow[t]{2}{*}{ lg_empl × managerial_lev7 } & & $0.0382 * * *$ \\
\hline & & $(0.00744)$ \\
\hline \multirow[t]{2}{*}{ lg_empl × managerial_lev8 } & & $0.0837 * * *$ \\
\hline & & $(0.0129)$ \\
\hline \multirow[t]{2}{*}{ managerial_lev3 } & & -0.150 \\
\hline & & $(0.250)$ \\
\hline \multirow[t]{2}{*}{ managerial_lev4 } & & $0.545^{*}$ \\
\hline & & $(0.318)$ \\
\hline \multirow[t]{2}{*}{ managerial_lev5 } & & $0.403^{* * *}$ \\
\hline & & $(0.125)$ \\
\hline \multirow[t]{2}{*}{ managerial_lev6 } & & 0.00793 \\
\hline & & $(0.0676)$ \\
\hline \multirow[t]{2}{*}{ managerial_lev7 } & & $-0.287 * * *$ \\
\hline & & $(0.0603)$ \\
\hline \multirow[t]{2}{*}{ managerial_lev8 } & & $-0.431 * * *$ \\
\hline & & $(0.113)$ \\
\hline \multirow[t]{2}{*}{ Constant } & $5.175^{* * *}$ & $5.205^{* * *}$ \\
\hline & $(0.0412)$ & $(0.0415)$ \\
\hline Observations & 3,330 & 3,330 \\
\hline R-squared & 0.691 & 0.711 \\
\hline
\end{tabular}




\section{Table 8}

\section{Within-Firm Changes in Skill Premia}

The dependent variable is the skill premium, or wage ratio (in logs), associated with a given job-level pair. The sample in the column "Middle-Bottom" is comprised of job-level pairs 14, 15, 24, and 25 ("overall wage inequality"), that in the column "Top-Middle" is comprised of job-level pairs 48, 49, 58, and 59 ("upper-tail wage inequality"), and that in the column "Top-Bottom" is comprised of job-level pairs 18, 19, 28, and 29 ("lower-tail wage inequality"). Firm size is measured as the number of employees (in logs). All regressions include firm, year, and job-level pair fixed effects. Standard errors (in parentheses) are clustered at the firm level. The sample period is from 2004 to 2013. *, **, and *** denotes significance at the $10 \%, 5 \%$, and $1 \%$ level, respectively.

\begin{tabular}{lccc}
\hline Job-Level Pairs & Middle-Bottom & Top-Middle & Top-Bottom \\
\hline \hline lg_empl & 0.0130 & $0.108^{* *}$ & $0.777^{* * *}$ \\
& $(0.0211)$ & $(0.0421)$ & $(0.275)$ \\
Constant & $0.466^{* * *}$ & 0.113 & $-4.213^{*}$ \\
& $(0.162)$ & $(0.321)$ & $(2.232)$ \\
& & & \\
Observations & 1,940 & 853 & 232 \\
R-squared & 0.716 & 0.811 & 0.880 \\
\hline
\end{tabular}




\section{Table 9}

\section{Firm Growth in Developed Countries}

This table shows for each country the first and last year in the sample, number of country-year observations, and change in average employment ("change in firm size") among the 50 (100) largest firms in the country between the first and last sample year. The sample is the merged LIS-Worldscope sample described in Section 5.3. The sample period is from 1981 to 2010.

\begin{tabular}{|c|c|c|c|c|c|c|c|c|}
\hline \multirow[b]{2}{*}{ Country } & \multicolumn{4}{|c|}{ Top 50 Firms } & \multicolumn{4}{|c|}{ Top 100 Firms } \\
\hline & $\begin{array}{l}\text { First } \\
\text { Year }\end{array}$ & Last Year & Obs. & $\begin{array}{l}\text { Change in } \\
\text { Firm Size }\end{array}$ & $\begin{array}{l}\text { First } \\
\text { Year }\end{array}$ & Last Year & Obs. & $\begin{array}{l}\text { Change in } \\
\text { Firm Size }\end{array}$ \\
\hline Australia & 1985 & 2001 & 4 & $37.1 \%$ & 1995 & 2001 & 2 & $16.2 \%$ \\
\hline Austria & 1994 & 2004 & 4 & $82.8 \%$ & 1997 & 2000 & 2 & $18.3 \%$ \\
\hline Belgium & 1988 & 2000 & 5 & $112.2 \%$ & 1992 & 2000 & 4 & $35.4 \%$ \\
\hline Canada & 1981 & 2010 & 10 & $73.1 \%$ & 1981 & 2010 & 10 & $80.7 \%$ \\
\hline Denmark & 1995 & 2010 & 5 & $-2.1 \%$ & 1995 & 2010 & 5 & $-4.3 \%$ \\
\hline Finland & 1987 & 2010 & 7 & $58.6 \%$ & 1991 & 2010 & 5 & $46.7 \%$ \\
\hline France & 1994 & 2005 & 3 & $48.3 \%$ & 1994 & 2005 & 3 & $40.3 \%$ \\
\hline Germany & 1984 & 2010 & 7 & $91.0 \%$ & 1984 & 2010 & 7 & $87.3 \%$ \\
\hline Greece & 1995 & 2010 & 5 & $192.6 \%$ & 1995 & 2010 & 5 & $201.7 \%$ \\
\hline Italy & 1987 & 2010 & 10 & $31.5 \%$ & 1987 & 2010 & 10 & $30.3 \%$ \\
\hline Netherlands & 1983 & 2010 & 8 & $107.9 \%$ & 1987 & 2010 & 7 & $87.1 \%$ \\
\hline Spain & 1995 & 2010 & 5 & $200.3 \%$ & 1995 & 2010 & 5 & $185.9 \%$ \\
\hline Sweden & 1987 & 1995 & 3 & $13.6 \%$ & 1987 & 1995 & 3 & $15.5 \%$ \\
\hline United Kingdom & 1986 & 2010 & 8 & $51.3 \%$ & 1986 & 2010 & 8 & $43.5 \%$ \\
\hline United States & 1986 & 2010 & 8 & $55.8 \%$ & 1986 & 2010 & 8 & $53.0 \%$ \\
\hline
\end{tabular}


Table 10

Wage Inequality and Firm Growth

The dependent variable is the log 90/10 wage differential. Firm size is measured as the average number of employees of the 50 (100) largest firms in a given country and year (in logs). The sample is the merged LIS-Worldscope sample described in Section 5.3. All regressions include country fixed effects. Those in columns (1) and (4) additionally include year fixed effects, while those in columns (2)-(3) and (5)-(6) include a linear time trend instead. Time trend is defined as the given year minus 1999. Robust standard errors are in parentheses. The sample period is from 1981 to 2010. *, **, and ${ }^{* * *}$ denotes significance at the $10 \%, 5 \%$, and $1 \%$ level, respectively.

\begin{tabular}{lcccccc}
\hline & \multicolumn{3}{c}{ Top 50 Firms } & \multicolumn{3}{c}{ Top 100 Firms } \\
\hline \hline \multirow{2}{*}{ lg_avg_empl } & $\mathbf{( 1 )}$ & $\mathbf{( 2 )}$ & $\mathbf{( 3 )}$ & $\mathbf{( 4 )}$ & $\mathbf{( 5 )}$ & $\mathbf{( 6 )}$ \\
& $0.211^{* * *}$ & & $0.145^{* *}$ & $0.206^{* * *}$ & & $0.183^{* * *}$ \\
& $(0.0739)$ & & $(0.0671)$ & $(0.0609)$ & & $(0.0562)$ \\
time_trend & & & & & $0.0111^{* * *}$ & $0.00668^{* * *}$ \\
& & $0.0104^{* * *}$ & $0.00656^{* * *}$ & & $(0.00127)$ & $(0.00172)$ \\
Constant & $(0.00139)$ & $(0.00193)$ & & & -0.527 \\
& $-1.227^{*}$ & $1.170^{* * *}$ & -0.270 & $-1.021^{*}$ & $1.170^{* * *}$ & $(0.522)$ \\
Observations & $(0.714)$ & $(0.0114)$ & $(0.665)$ & $(0.539)$ & $(0.00170)$ & 84 \\
R-squared & 92 & 92 & 92 & 84 & 84 & 0.923 \\
\hline
\end{tabular}


Figure 1

Upper- and Lower-Tail Wage Inequality in the UK (1970-2009)

(a)

Men

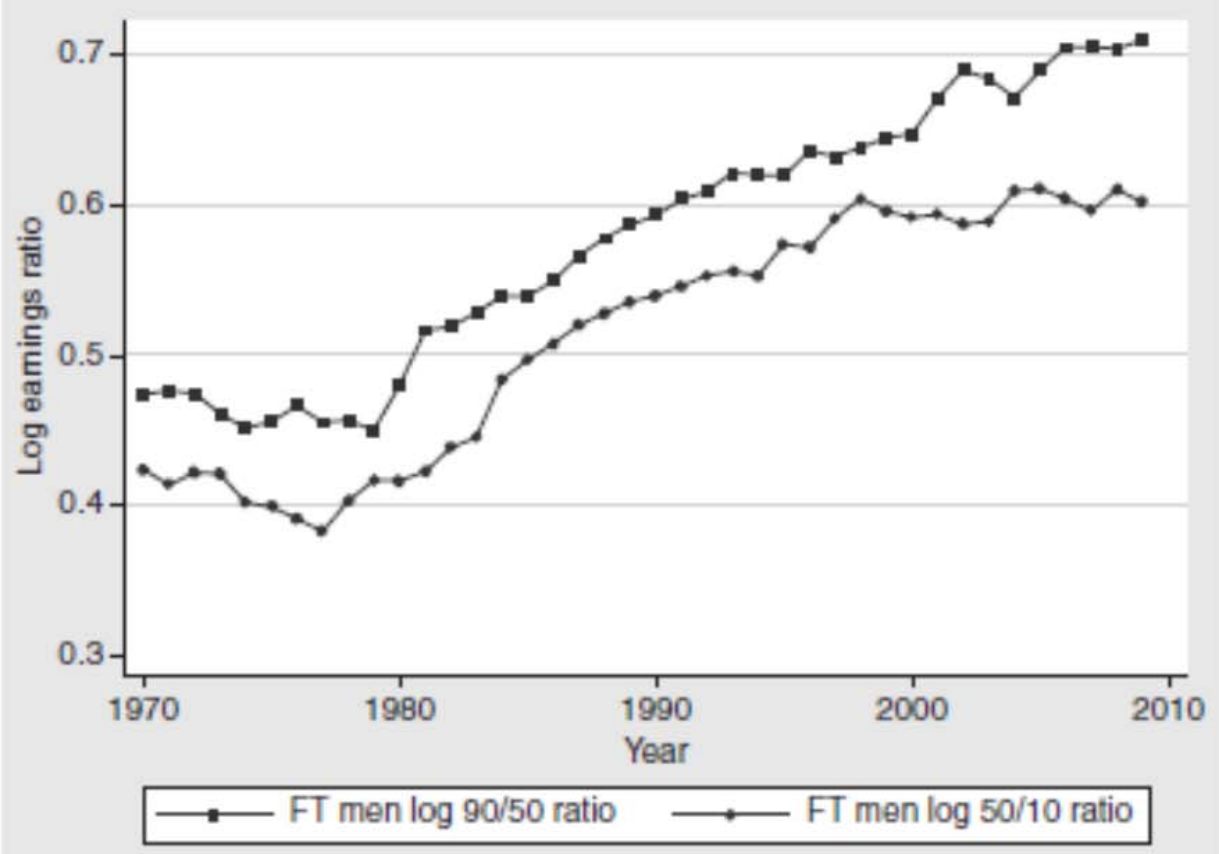

(b)

Women

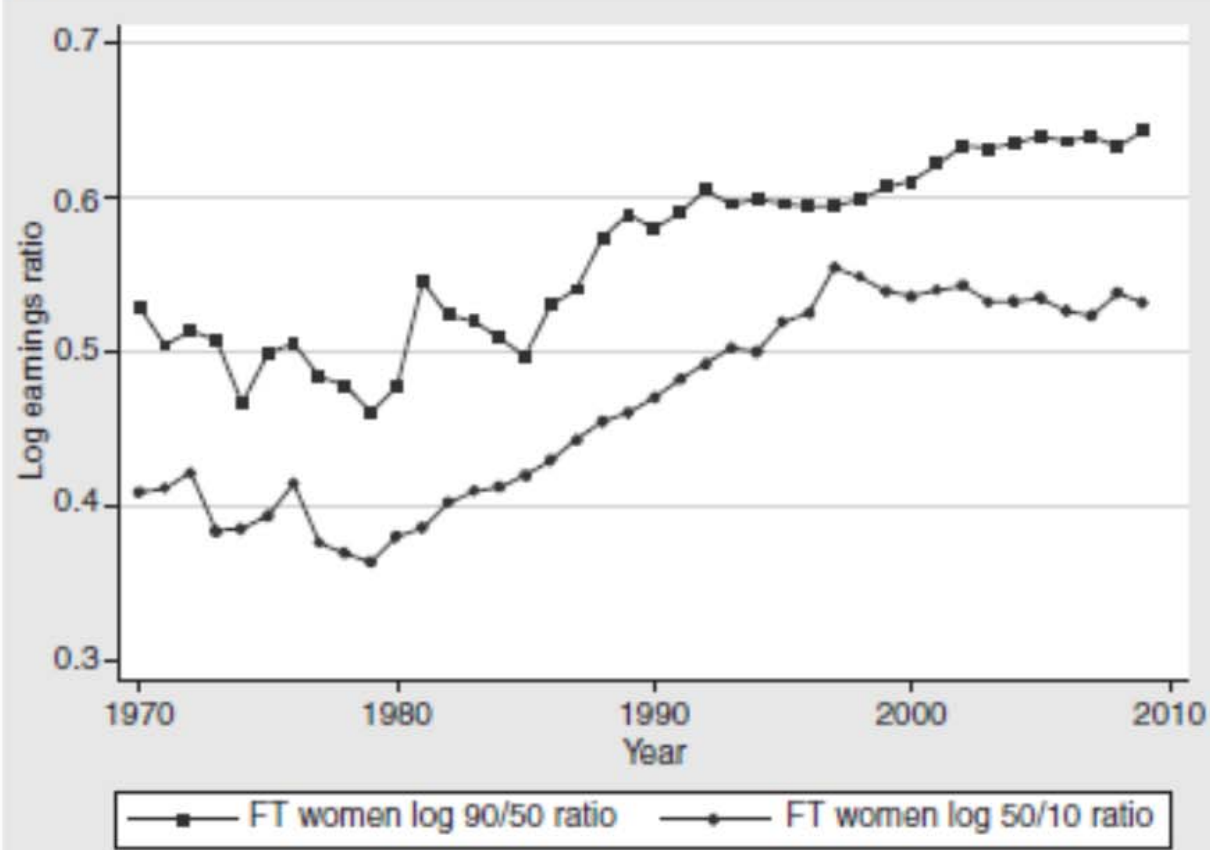

Source: Machin (2010, Figure 11.2). 
Figure 2

Upper- and Lower-Tail Wage Inequality in the US (1974-2005)

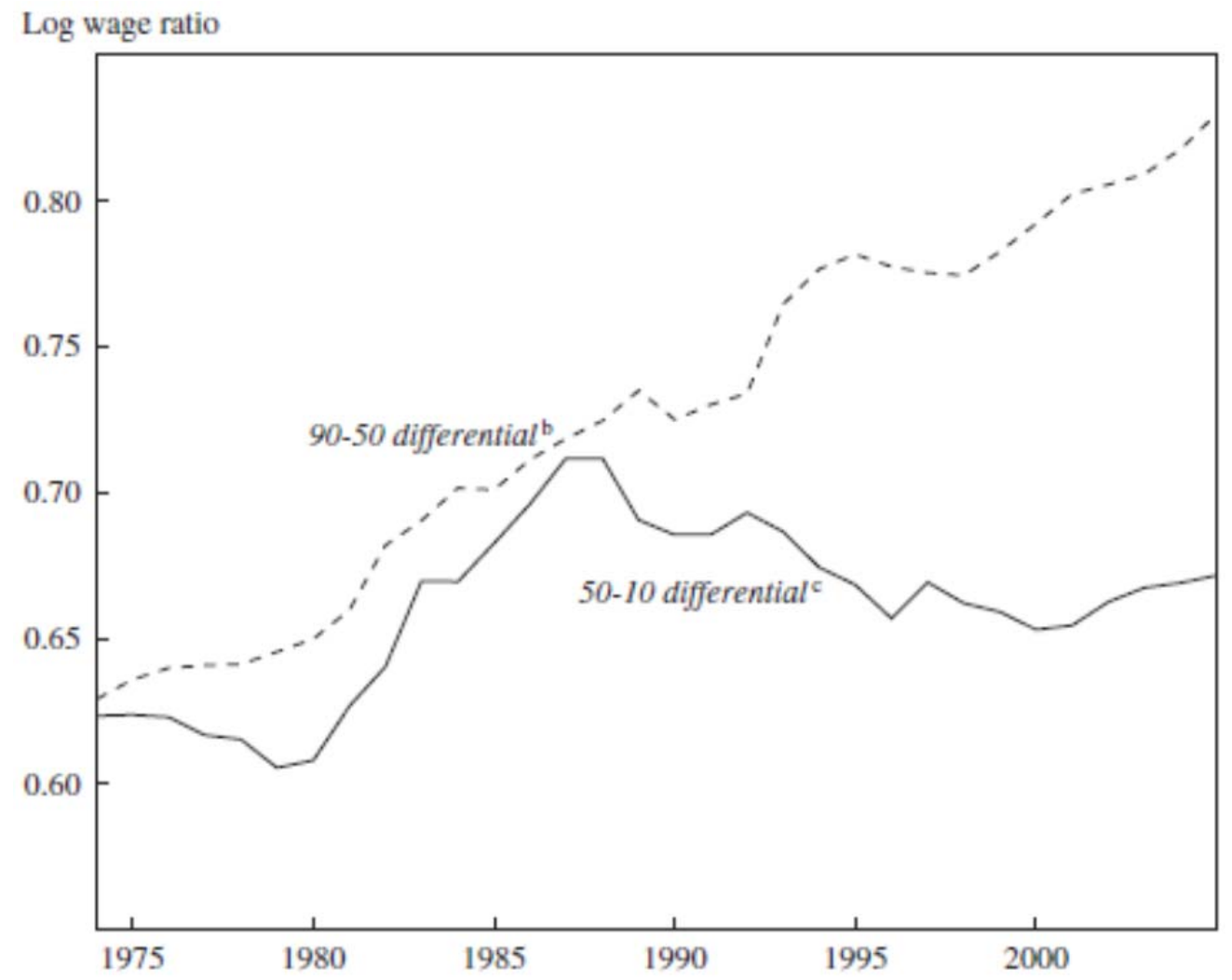

Source: Goldin and Katz (2007, Figure 3). 
Appendix 


\section{Appendix Table A1 \\ Original Ten IDS Job Levels}

This table presents variants of the regressions in Table 4 in which the original ten IDS job levels are used. All regressions include year fixed effects. Standard errors (in parentheses) are clustered at the firm level. The sample period is from 2004 to $2013 . *, * *$, and $* * *$ denotes significance at the $10 \%, 5 \%$, and $1 \%$ level, respectively.

Panel (A):

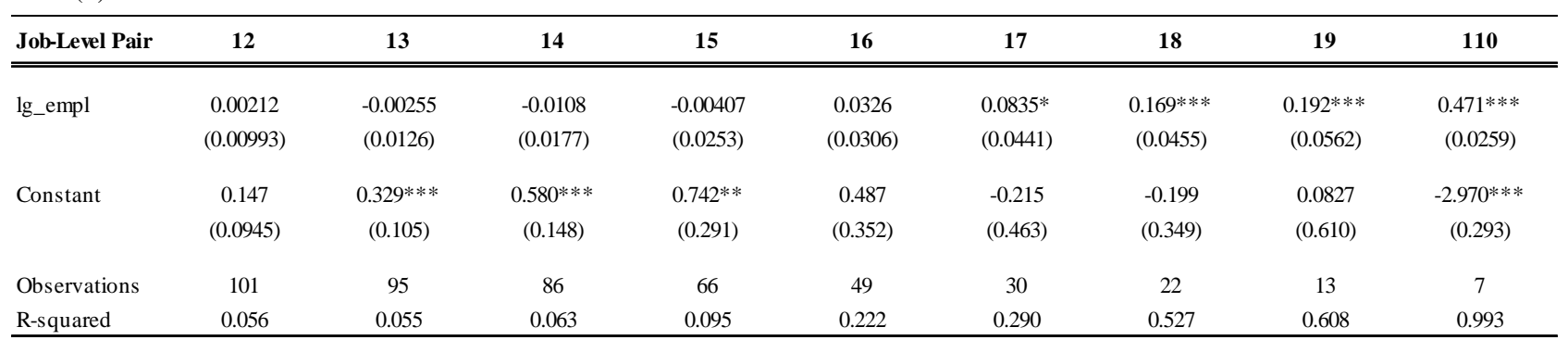

Panel (B):

\begin{tabular}{|c|c|c|c|c|c|c|c|c|}
\hline Job-Level Pair & 23 & 24 & 25 & 26 & 27 & 28 & 29 & 210 \\
\hline \multirow[t]{2}{*}{ lg_empl } & -0.00204 & -0.00671 & 0.00522 & 0.00735 & $0.0359 * * *$ & $0.0861 * * *$ & $0.160 * * *$ & $0.176^{* * *}$ \\
\hline & $(0.00308)$ & $(0.00482)$ & $(0.00642)$ & $(0.00937)$ & $(0.0115)$ & $(0.0153)$ & $(0.0257)$ & $(0.0374)$ \\
\hline \multirow[t]{2}{*}{ Constant } & $0.177 * * *$ & $0.387 * * *$ & $0.482 * * *$ & $0.637 * * *$ & $0.582 * * *$ & $0.467 * *$ & 0.216 & 0.395 \\
\hline & $(0.0272)$ & $(0.0485)$ & $(0.0651)$ & $(0.0938)$ & $(0.133)$ & $(0.214)$ & (0.179) & $(0.241)$ \\
\hline Observations & 553 & 467 & 447 & 378 & 292 & 191 & 73 & 22 \\
\hline R-squared & 0.028 & 0.047 & 0.064 & 0.047 & 0.147 & 0.376 & 0.506 & 0.742 \\
\hline
\end{tabular}

Panel (C):

\begin{tabular}{|c|c|c|c|c|c|c|c|}
\hline Job-Level Pair & 34 & 35 & 36 & 37 & 38 & 39 & 310 \\
\hline lg_empl & $\begin{array}{c}-0.0109 * * * \\
(0.00370)\end{array}$ & $\begin{array}{l}-0.00493 \\
(0.00545)\end{array}$ & $\begin{array}{l}-0.00905 \\
(0.00659)\end{array}$ & $\begin{array}{c}0.00584 \\
(0.00883)\end{array}$ & $\begin{array}{c}0.0605^{* * *} \\
(0.0115)\end{array}$ & $\begin{array}{c}0.133 * * * \\
(0.0256)\end{array}$ & $\begin{array}{c}0.152 * * * \\
(0.0382)\end{array}$ \\
\hline Constant & $\begin{array}{c}0.268 * * * \\
(0.0337)\end{array}$ & $\begin{array}{c}0.391 * * * \\
(0.0511)\end{array}$ & $\begin{array}{c}0.632 * * * \\
(0.0675)\end{array}$ & $\begin{array}{c}0.662 * * * \\
(0.0826)\end{array}$ & $\begin{array}{c}0.482 * * * \\
(0.123)\end{array}$ & $\begin{array}{c}0.198 \\
(0.196)\end{array}$ & $\begin{array}{c}0.714^{* *} \\
(0.326)\end{array}$ \\
\hline Observations & 660 & 597 & 511 & 415 & 251 & 99 & 36 \\
\hline R-squared & 0.037 & 0.029 & 0.061 & 0.027 & 0.209 & 0.398 & 0.361 \\
\hline
\end{tabular}

Panel (D):

\begin{tabular}{|c|c|c|c|c|c|c|}
\hline Job-Level Pair & 45 & 46 & 47 & 48 & 49 & 410 \\
\hline \multirow[t]{2}{*}{ lg_empl } & 0.00412 & 0.00712 & $0.0187 *$ & $0.0717 * * *$ & $0.147 * * *$ & $0.159 * * *$ \\
\hline & $(0.00534)$ & $(0.00750)$ & $(0.0103)$ & $(0.0152)$ & $(0.0292)$ & $(0.0370)$ \\
\hline \multirow[t]{2}{*}{ Constant } & $0.147 * * *$ & $0.320 * * *$ & $0.396 * * *$ & 0.246 & $0.476 * * *$ & 0.247 \\
\hline & $(0.0445)$ & $(0.0671)$ & $(0.0850)$ & $(0.154)$ & $(0.166)$ & $(0.284)$ \\
\hline Observations & 631 & 542 & 436 & 275 & 109 & 46 \\
\hline R-squared & 0.024 & 0.027 & 0.044 & 0.239 & 0.347 & 0.407 \\
\hline
\end{tabular}




\section{Appendix Table A1 (continued)}

\begin{tabular}{lccccc} 
Panel (E): & \multicolumn{7}{c}{} \\
\hline Job-Level Pair & $\mathbf{5 6}$ & $\mathbf{5 7}$ & $\mathbf{5 8}$ & $\mathbf{5 9}$ & $\mathbf{5 1 0}$ \\
\hline \hline lg_empl & -0.000639 & $0.0205^{* * *}$ & $0.0566^{* * *}$ & $0.105^{* * *}$ & $0.102^{* * *}$ \\
& $(0.00429)$ & $(0.00660)$ & $(0.00791)$ & $(0.0126)$ & $(0.0188)$ \\
Constant & $0.207^{* * *}$ & $0.271^{* * *}$ & 0.147 & $0.330^{* * *}$ & $0.888^{* * *}$ \\
& $(0.0423)$ & $(0.0569)$ & $(0.0940)$ & $(0.0718)$ & $(0.257)$ \\
Observations & 648 & 542 & 399 & 202 & 112 \\
R-squared & 0.023 & 0.061 & 0.195 & 0.323 & 0.266 \\
\hline
\end{tabular}

Panel (F):

\begin{tabular}{lcccc}
\hline Job-Level Pair & $\mathbf{6 7}$ & $\mathbf{6 8}$ & $\mathbf{6 9}$ & $\mathbf{6 1 0}$ \\
\hline \hline lg_empl & $0.0201^{* * *}$ & $0.0413^{* * *}$ & $0.0887^{* * *}$ & $0.0914^{* * *}$ \\
& $(0.00450)$ & $(0.00617)$ & $(0.0111)$ & $(0.0132)$ \\
Constant & $0.0874^{*}$ & 0.0916 & $0.276^{* * *}$ & $0.742^{* * *}$ \\
& $(0.0472)$ & $(0.0702)$ & $(0.0630)$ & $(0.143)$ \\
& & & & \\
Observations & 693 & 557 & 346 & 193 \\
R-squared & 0.071 & 0.160 & 0.272 & 0.221 \\
\hline
\end{tabular}

Panel (G):

\begin{tabular}{lccc}
\hline Job-Level Pair & $\mathbf{7 8}$ & $\mathbf{7 9}$ & $\mathbf{7 1 0}$ \\
\hline \hline lg_empl & $0.0176^{* * *}$ & $0.0559 * * *$ & $0.0618^{* * *}$ \\
& $(0.00426)$ & $(0.00928)$ & $(0.0124)$ \\
Constant & 0.0493 & $0.119^{* *}$ & $0.602^{* * *}$ \\
& $(0.0405)$ & $(0.0529)$ & $(0.137)$ \\
Observations & 576 & 391 & 214 \\
R-squared & 0.059 & 0.166 & 0.131 \\
\hline
\end{tabular}

Panel (H):

\begin{tabular}{lcc}
\hline Job-Level Pair & $\mathbf{8 9}$ & $\mathbf{8 1 0}$ \\
\hline \hline lg_empl & $0.0326^{* * *}$ & $0.0457^{* * *}$ \\
& $(0.00822)$ & $(0.0103)$ \\
Constant & 0.0310 & $0.361^{* * *}$ \\
& $(0.0468)$ & $(0.0790)$ \\
Observations & 397 & 213 \\
R-squared & 0.101 & 0.106 \\
\hline
\end{tabular}

Panel (I):

\begin{tabular}{lc}
\hline Job-Level Pair & $\mathbf{9 1 0}$ \\
\hline \hline lg_empl & $\begin{array}{c}0.0244^{* * *} \\
(0.00875)\end{array}$ \\
Constant & $0.272^{* * *}$ \\
& $(0.0923)$ \\
Observations & 201 \\
R-squared & 0.050 \\
\hline
\end{tabular}




\section{Appendix Table A2 \\ Measuring Firm Size Using Firms’ Sales}

This table presents variants of the regressions in Table 4 in which firm size is measured using firms' sales (in logs). All regressions include year fixed effects. Standard errors (in parentheses) are clustered at the firm level. The sample period is from 2004 to $2013 . *, * *$, and $* * *$ denotes significance at the $10 \%, 5 \%$, and $1 \%$ level, respectively.

Panel (A):

\begin{tabular}{|c|c|c|c|c|c|c|c|c|}
\hline Job-Level Pair & 12 & 13 & 14 & 15 & 16 & 17 & 18 & 19 \\
\hline \multirow[t]{2}{*}{ lg_sales } & -0.000724 & -0.00665 & 0.00221 & 0.00122 & $0.0246 * *$ & $0.0765 * * *$ & $0.133 * * *$ & $0.150 * * *$ \\
\hline & $(0.00283)$ & $(0.00431)$ & $(0.00582)$ & $(0.00842)$ & $(0.0102)$ & $(0.0151)$ & (0.0279) & $(0.0354)$ \\
\hline \multirow[t]{2}{*}{ Constant } & $0.166^{* * *}$ & $0.435 * * *$ & $0.484 * * *$ & $0.668 * * *$ & $0.503 * * *$ & -0.00329 & -0.330 & -0.729 \\
\hline & $(0.0432)$ & (0.0699) & $(0.0943)$ & $(0.134)$ & (0.183) & $(0.298)$ & (0.379) & $(0.575)$ \\
\hline Observations & 580 & 490 & 462 & 394 & 302 & 198 & 78 & 26 \\
\hline R-squared & 0.024 & 0.050 & 0.072 & 0.042 & 0.109 & 0.312 & 0.417 & 0.618 \\
\hline
\end{tabular}

Panel (B):

\begin{tabular}{lccccccc}
\hline Job-Level Pair & $\mathbf{2 3}$ & $\mathbf{2 4}$ & $\mathbf{2 5}$ & $\mathbf{2 6}$ & $\mathbf{2 7}$ & $\mathbf{2 8}$ & $\mathbf{2 9}$ \\
\hline \hline lg_sales & $-0.0143^{* * *}$ & $-0.0119^{* *}$ & $-0.0162^{* *}$ & -0.00548 & $0.0472^{* * *}$ & $0.110^{* * *}$ & $0.110^{* * *}$ \\
& $(0.00297)$ & $(0.00476)$ & $(0.00655)$ & $(0.00757)$ & $(0.0102)$ & $(0.0235)$ & $(0.0371)$ \\
& & & & & & & \\
Constant & $0.405^{* * *}$ & $0.537 * *$ & $0.812^{* * *}$ & $0.780^{* * *}$ & 0.242 & -0.527 & 0.245 \\
& $(0.0474)$ & $(0.0770)$ & $(0.106)$ & $(0.127)$ & $(0.173)$ & $(0.372)$ & $(0.572)$ \\
Observations & 686 & 618 & 532 & 432 & 261 & 104 & 40 \\
R-squared & 0.066 & 0.049 & 0.078 & 0.024 & 0.156 & 0.369 & 0.249 \\
\hline
\end{tabular}

Panel (C):

\begin{tabular}{lcccccc}
\hline Job-Level Pair & $\mathbf{3 4}$ & $\mathbf{3 5}$ & $\mathbf{3 6}$ & $\mathbf{3 7}$ & $\mathbf{3 8}$ & $\mathbf{3 9}$ \\
\hline \hline lg_sales & -0.00229 & -0.00288 & 0.00875 & $0.0591^{* * *}$ & $0.111^{* * *}$ & $0.137^{* * *}$ \\
& $(0.00465)$ & $(0.00680)$ & $(0.00877)$ & $(0.0141)$ & $(0.0293)$ & $(0.0339)$ \\
& & & & & & \\
Constant & $0.214^{* * *}$ & $0.424^{* * *}$ & $0.402^{* * *}$ & -0.0900 & -0.0991 & $-1.101^{*}$ \\
& $(0.0726)$ & $(0.108)$ & $(0.140)$ & $(0.239)$ & $(0.373)$ & $(0.551)$ \\
Observations & 648 & 557 & 445 & 280 & 112 & 48 \\
R-squared & 0.021 & 0.022 & 0.026 & 0.193 & 0.287 & 0.368 \\
\hline
\end{tabular}

Panel (D):

\begin{tabular}{lccccc}
\hline Job-Level Pair & $\mathbf{4 5}$ & $\mathbf{4 6}$ & $\mathbf{4 7}$ & $\mathbf{4 8}$ & $\mathbf{4 9}$ \\
\hline \hline lg_sales & -0.00500 & $0.0171^{* * *}$ & $0.0499^{* * *}$ & $0.0956^{* * *}$ & $0.101^{* * *}$ \\
& $(0.00441)$ & $(0.00619)$ & $(0.00756)$ & $(0.0138)$ & $(0.0186)$ \\
Constant & $0.279^{* * *}$ & $0.170^{*}$ & -0.203 & $-0.530^{* *}$ & 0.147 \\
& $(0.0720)$ & $(0.0970)$ & $(0.135)$ & $(0.266)$ & $(0.331)$ \\
& & & & & \\
Observations & 666 & 557 & 412 & 209 & 115 \\
R-squared & 0.032 & 0.053 & 0.183 & 0.308 & 0.275 \\
\hline
\end{tabular}




\section{Appendix Table A2 (continued)}

Panel (E):

\begin{tabular}{lcccc}
\hline Job-Level Pair & $\mathbf{5 6}$ & $\mathbf{5 7}$ & $\mathbf{5 8}$ & $\mathbf{5 9}$ \\
\hline \hline lg_sales & $0.0134^{* * *}$ & $0.0362^{* * *}$ & $0.0684^{* * *}$ & $0.0785^{* * *}$ \\
& $(0.00388)$ & $(0.00539)$ & $(0.0108)$ & $(0.0130)$ \\
Constant & 0.0384 & $-0.165^{*}$ & -0.324 & 0.149 \\
& $(0.0683)$ & $(0.0989)$ & $(0.230)$ & $(0.206)$ \\
Observations & 716 & 577 & 361 & 203 \\
R-squared & 0.051 & 0.150 & 0.212 & 0.204 \\
\hline
\end{tabular}

Panel (F):

\begin{tabular}{lccc}
\hline Job-Level Pair & $\mathbf{6 7}$ & $\mathbf{6 8}$ & $\mathbf{6 9}$ \\
\hline \hline lg_sales & $0.0153^{* * *}$ & $0.0418^{* * *}$ & $0.0514^{* * *}$ \\
& $(0.00352)$ & $(0.00843)$ & $(0.0111)$ \\
Constant & -0.0488 & -0.0943 & 0.130 \\
& $(0.0585)$ & $(0.107)$ & $(0.175)$ \\
Observations & 598 & 407 & 225 \\
R-squared & 0.055 & 0.133 & 0.119 \\
\hline
\end{tabular}

Panel (G):

\begin{tabular}{lcc}
\hline Job-Level Pair & $\mathbf{7 8}$ & $\mathbf{7 9}$ \\
\hline \hline lg_sales & $0.0301^{* * *}$ & $0.0382^{* * *}$ \\
& $(0.00712)$ & $(0.0104)$ \\
Constant & -0.154 & 0.109 \\
& $(0.104)$ & $(0.164)$ \\
Observations & 415 & 224 \\
R-squared & 0.091 & 0.098 \\
\hline
\end{tabular}

Panel (H):

\begin{tabular}{lc}
\hline Job-Level Pair & $\mathbf{8 9}$ \\
\hline \hline lg_sales & $0.0262 * * *$ \\
& $(0.00789)$ \\
Constant & 0.0667 \\
& $(0.126)$ \\
Observations & 212 \\
R-squared & 0.068 \\
\hline
\end{tabular}




\section{Appendix Table A3 \\ Winsorizing Firm Size at the 1\% Level}

This table presents variants of the regressions in Table 4 in which firm size is winsorized at the $1 \%$ level. All regressions include year fixed effects. Standard errors (in parentheses) are clustered at the firm level. The sample period is from 2004 to $2013 . *$,**, and $* * *$ denotes significance at the $10 \%, 5 \%$, and $1 \%$ level, respectively.

\begin{tabular}{|c|c|c|c|c|c|c|c|c|}
\hline Job-Level Pair & 12 & 13 & 14 & 15 & 16 & 17 & 18 & 19 \\
\hline \multirow[t]{2}{*}{ lg_empl } & -0.000850 & -0.00470 & 0.00756 & 0.00877 & $0.0343^{* * *}$ & $0.0805^{* * *}$ & $0.157 * * *$ & $0.172 * * *$ \\
\hline & $(0.00323)$ & $(0.00482)$ & $(0.00617)$ & $(0.00862)$ & $(0.0109)$ & $(0.0141)$ & $(0.0258)$ & $(0.0410)$ \\
\hline \multirow[t]{2}{*}{ Constant } & $0.169 * * *$ & $0.374 * * *$ & $0.465^{* * *}$ & $0.628 * * *$ & $0.597 * * *$ & $0.521^{* *}$ & -0.195 & 0.417 \\
\hline & $(0.0277)$ & $(0.0473)$ & $(0.0642)$ & $(0.0889)$ & $(0.129)$ & $(0.207)$ & (0.196) & $(0.264)$ \\
\hline Observations & 559 & 474 & 449 & 383 & 295 & 193 & 74 & 23 \\
\hline R-squared & 0.024 & 0.041 & 0.070 & 0.050 & 0.143 & 0.366 & 0.503 & 0.725 \\
\hline
\end{tabular}

Panel (B):

\begin{tabular}{|c|c|c|c|c|c|c|c|}
\hline Job-Level Pair & 23 & 24 & 25 & 26 & 27 & 28 & 29 \\
\hline lg_empl & $\begin{array}{c}-0.0106 * * * \\
(0.00348)\end{array}$ & $\begin{array}{l}-0.00453 \\
(0.00509)\end{array}$ & $\begin{array}{l}-0.00814 \\
(0.00630)\end{array}$ & $\begin{array}{c}0.00588 \\
(0.00840)\end{array}$ & $\begin{array}{c}0.0543^{* * *} \\
(0.0110)\end{array}$ & $\begin{array}{c}0.132 * * * \\
(0.0252)\end{array}$ & $\begin{array}{c}0.152 * * * \\
(0.0382)\end{array}$ \\
\hline Constant & $\begin{array}{c}0.266 * * * \\
(0.0321)\end{array}$ & $\begin{array}{c}0.388^{* * *} \\
(0.0483)\end{array}$ & $\begin{array}{c}0.624^{* * *} \\
(0.0656)\end{array}$ & $\begin{array}{c}0.662 * * * \\
(0.0800)\end{array}$ & $\begin{array}{c}0.536 * * * \\
(0.122)\end{array}$ & $\begin{array}{c}0.209 \\
(0.193)\end{array}$ & $\begin{array}{c}0.715^{* *} \\
(0.326)\end{array}$ \\
\hline Observations & 660 & 597 & 511 & 415 & 251 & 99 & 36 \\
\hline R-squared & 0.038 & 0.029 & 0.060 & 0.027 & 0.196 & 0.399 & 0.361 \\
\hline
\end{tabular}

Panel (C):

\begin{tabular}{lcccccc}
\hline Job-Level Pair & $\mathbf{3 4}$ & $\mathbf{3 5}$ & $\mathbf{3 6}$ & $\mathbf{3 7}$ & $\mathbf{3 8}$ & $\mathbf{3 9}$ \\
\hline \hline lg_empl & 0.00449 & 0.00782 & $0.0184^{*}$ & $0.0660^{* * *}$ & $0.142^{* * *}$ & $0.156^{* * *}$ \\
& $(0.00506)$ & $(0.00706)$ & $(0.00977)$ & $(0.0144)$ & $(0.0284)$ & $(0.0376)$ \\
& & & & & & \\
Constant & $0.145^{* * *}$ & $0.314^{* * *}$ & $0.399^{* * *}$ & $0.293^{* *}$ & $0.504^{* * *}$ & 0.272 \\
& $(0.0423)$ & $(0.0639)$ & $(0.0817)$ & $(0.148)$ & $(0.162)$ & $(0.288)$ \\
& & & & & & 109 \\
Observations & 631 & 542 & 436 & 275 & 0.345 & 0.402 \\
R-squared & 0.024 & 0.028 & 0.045 & 0.229 & 0
\end{tabular}

Panel (D):

\begin{tabular}{lccccc}
\hline Job-Level Pair & $\mathbf{4 5}$ & $\mathbf{4 6}$ & $\mathbf{4 7}$ & $\mathbf{4 8}$ & $\mathbf{4 9}$ \\
\hline \hline lg_empl & -0.000185 & $0.0193^{* * *}$ & $0.0510^{* * *}$ & $0.0985^{* * *}$ & $0.0901^{* * *}$ \\
& $(0.00401)$ & $(0.00612)$ & $(0.00765)$ & $(0.0136)$ & $(0.0195)$ \\
& & & & & \\
Constant & $0.203^{* * *}$ & $0.280^{* * *}$ & $0.189^{* *}$ & $0.365^{* * *}$ & $0.996^{* * *}$ \\
& $(0.0403)$ & $(0.0545)$ & $(0.0919)$ & $(0.0774)$ & $(0.266)$ \\
Observations & 648 & 542 & 399 & 202 & 112 \\
R-squared & 0.023 & 0.060 & 0.186 & 0.311 & 0.243 \\
\hline
\end{tabular}




\section{Appendix Table A3 (continued)}

Panel (E):

\begin{tabular}{lcccc}
\hline Job-Level Pair & $\mathbf{5 6}$ & $\mathbf{5 7}$ & $\mathbf{5 8}$ & $\mathbf{5 9}$ \\
\hline \hline lg_empl & $0.0186^{* * *}$ & $0.0368^{* * *}$ & $0.0823^{* * *}$ & $0.0823^{* * *}$ \\
& $(0.00434)$ & $(0.00602)$ & $(0.0104)$ & $(0.0124)$ \\
& & & & \\
Constant & $0.0993^{* *}$ & $0.127^{*}$ & $0.312^{* * *}$ & $0.808^{* * *}$ \\
& $(0.0466)$ & $(0.0688)$ & $(0.0593)$ & $(0.141)$ \\
Observations & 693 & 557 & 346 & 193 \\
R-squared & 0.070 & 0.149 & 0.265 & 0.209 \\
\hline
\end{tabular}

Panel (F):

\begin{tabular}{lccc}
\hline Job-Level Pair & $\mathbf{6 7}$ & $\mathbf{6 8}$ & $\mathbf{6 9}$ \\
\hline \hline lg_empl & $0.0155^{* * *}$ & $0.0506^{* * *}$ & $0.0576^{* * * *}$ \\
& $(0.00433)$ & $(0.00933)$ & $(0.0116)$ \\
Constant & 0.0644 & $0.149^{* * *}$ & $0.634^{* * *}$ \\
& $(0.0404)$ & $(0.0532)$ & $(0.136)$ \\
Observations & 576 & 391 & 214 \\
R-squared & 0.055 & 0.156 & 0.128 \\
\hline
\end{tabular}

Panel (G):

\begin{tabular}{lcc}
\hline Job-Level Pair & $\mathbf{7 8}$ & $\mathbf{7 9}$ \\
\hline \hline lg_empl & $\begin{array}{c}0.0312^{* * *} \\
(0.00769)\end{array}$ & $\begin{array}{c}0.0429 * * * \\
(0.00946)\end{array}$ \\
& & \\
Constant & 0.0390 & $0.383^{* * *}$ \\
& $(0.0438)$ & $(0.0725)$ \\
Observations & 397 & 213 \\
R-squared & 0.102 & 0.105 \\
\hline
\end{tabular}

Panel (H):

\begin{tabular}{lc}
\hline Job-Level Pair & $\mathbf{8 9}$ \\
\hline \hline lg_empl & $\begin{array}{c}0.0226^{* * *} \\
(0.00790)\end{array}$ \\
& $0.287^{* * *}$ \\
Constant & $(0.0883)$ \\
& 201 \\
Observations & 0.048 \\
R-squared & \\
\hline
\end{tabular}




\section{Appendix Table A4 \\ Within-Industry Analysis}

This table presents variants of the regressions in Table 4 which include both year and 2-digit SIC industry fixed effects. Standard errors (in parentheses) are clustered at the firm level. The sample period is from 2004 to 2013. *, **, and *** denotes significance at the $10 \%, 5 \%$, and $1 \%$ level, respectively.

Panel (A):

\begin{tabular}{|c|c|c|c|c|c|c|c|c|}
\hline Job-Level Pair & 12 & 13 & 14 & 15 & 16 & 17 & 18 & 19 \\
\hline \multirow[t]{2}{*}{ lg_empl } & -0.00313 & -0.00906 & -0.0131 & -0.0123 & 0.0175 & $0.0491 * * *$ & $0.107 * *$ & $0.185^{*}$ \\
\hline & $(0.00435)$ & (0.00813) & $(0.0101)$ & (0.00907) & $(0.0127)$ & $(0.0159)$ & $(0.0414)$ & $(0.0991)$ \\
\hline \multirow[t]{2}{*}{ Constant } & $0.280 * * *$ & $0.125^{*}$ & $0.515^{* * *}$ & $0.860 * * *$ & $0.951 * * *$ & $0.736 * * *$ & $0.592 * *$ & -0.104 \\
\hline & (0.0337) & $(0.0647)$ & $(0.0845)$ & $(0.0948)$ & $(0.113)$ & $(0.235)$ & (0.289) & (1.217) \\
\hline Observations & 552 & 468 & 442 & 377 & 291 & 190 & 73 & 22 \\
\hline R-squared & 0.155 & 0.178 & 0.287 & 0.336 & 0.380 & 0.588 & 0.680 & 0.949 \\
\hline
\end{tabular}

Panel (B):

\begin{tabular}{|c|c|c|c|c|c|c|c|}
\hline Job-Level Pair & 23 & 24 & 25 & 26 & 27 & 28 & 29 \\
\hline lg_empl & $\begin{array}{c}-0.0154 * * * \\
(0.00455)\end{array}$ & $\begin{array}{c}-0.0207 * * * \\
(0.00619)\end{array}$ & $\begin{array}{c}-0.0173 * * \\
(0.00672)\end{array}$ & $\begin{array}{c}-0.0101 \\
(0.00878)\end{array}$ & $\begin{array}{c}0.0313 * * \\
(0.0128)\end{array}$ & $\begin{array}{c}0.0817 * * \\
(0.0324)\end{array}$ & $\begin{array}{r}0.224 * * \\
(0.104)\end{array}$ \\
\hline Constant & $\begin{array}{c}0.577^{* * *} \\
(0.0314)\end{array}$ & $\begin{array}{c}0.739 * * * \\
(0.0775)\end{array}$ & $\begin{array}{c}0.953^{* * *} \\
(0.0590)\end{array}$ & $\begin{array}{c}0.581^{* * *} \\
(0.0704)\end{array}$ & $\begin{array}{c}0.402^{* * *} \\
(0.134)\end{array}$ & $\begin{array}{l}-0.462 \\
(0.511)\end{array}$ & $\begin{array}{l}-0.648 \\
(1.225)\end{array}$ \\
\hline Observations & 652 & 589 & 506 & 412 & 249 & 99 & 36 \\
\hline R-squared & 0.194 & 0.289 & 0.347 & 0.351 & 0.443 & 0.607 & 0.859 \\
\hline
\end{tabular}

Panel (C):

\begin{tabular}{lcccccc}
\hline Job-Level Pair & $\mathbf{3 4}$ & $\mathbf{3 5}$ & $\mathbf{3 6}$ & $\mathbf{3 7}$ & $\mathbf{3 8}$ & $\mathbf{3 9}$ \\
\hline \hline lg_empl & -0.00296 & 0.000319 & 0.00739 & $0.0417^{* * *}$ & $0.110^{* * *}$ & 0.0949 \\
& $(0.00477)$ & $(0.00611)$ & $(0.00864)$ & $(0.0123)$ & $(0.0289)$ & $(0.0571)$ \\
& & & & & & \\
Constant & $0.385^{* * *}$ & $0.700^{* * *}$ & $0.394^{* * *}$ & $0.514^{* * *}$ & -0.0876 & 0.212 \\
& $(0.0384)$ & $(0.0475)$ & $(0.0619)$ & $(0.195)$ & $(0.401)$ & $(0.703)$ \\
& & & & & & \\
Observations & 622 & 537 & 434 & 274 & 109 & 46 \\
R-squared & 0.265 & 0.283 & 0.319 & 0.432 & 0.596 & 0.790 \\
\hline
\end{tabular}

Panel (D):

\begin{tabular}{lccccc}
\hline Job-Level Pair & $\mathbf{4 5}$ & $\mathbf{4 6}$ & $\mathbf{4 7}$ & $\mathbf{4 8}$ & $\mathbf{4 9}$ \\
\hline \hline lg_empl & 0.00647 & $0.0231^{* * *}$ & $0.0516^{* * *}$ & $0.0912^{* * *}$ & $0.111^{* * *}$ \\
& $(0.00540)$ & $(0.00732)$ & $(0.0101)$ & $(0.0174)$ & $(0.0293)$ \\
Constant & $0.323^{* * *}$ & $0.188^{* *}$ & -0.0307 & 0.248 & $0.402^{*}$ \\
& $(0.0434)$ & $(0.0945)$ & $(0.138)$ & $(0.246)$ & $(0.232)$ \\
& & & & & \\
Observations & 642 & 539 & 397 & 201 & 111 \\
R-squared & 0.150 & 0.227 & 0.335 & 0.510 & 0.565 \\
\hline
\end{tabular}




\section{Appendix Table A4 (continued)}

Panel (E):

\begin{tabular}{lcccc}
\hline Job-Level Pair & $\mathbf{5 6}$ & $\mathbf{5 7}$ & $\mathbf{5 8}$ & $\mathbf{5 9}$ \\
\hline \hline lg_empl & $0.0161^{* * *}$ & $0.0348^{* * *}$ & $0.0786^{* * *}$ & $0.0889^{* * *}$ \\
& $(0.00518)$ & $(0.00626)$ & $(0.0141)$ & $(0.0189)$ \\
Constant & 0.0477 & $0.114^{*}$ & 0.342 & $0.954^{* * *}$ \\
& $(0.0386)$ & $(0.0598)$ & $(0.323)$ & $(0.209)$ \\
Observations & 689 & 554 & 344 & 192 \\
R-squared & 0.212 & 0.309 & 0.430 & 0.493 \\
\hline
\end{tabular}

Panel (F):

\begin{tabular}{lccc}
\hline Job-Level Pair & $\mathbf{6 7}$ & $\mathbf{6 8}$ & $\mathbf{6 9}$ \\
\hline \hline lg_empl & $0.0144^{* *}$ & $0.0488^{* * *}$ & $0.0434^{* *}$ \\
& $(0.00574)$ & $(0.0125)$ & $(0.0185)$ \\
& & & \\
Constant & $0.129 * * *$ & -0.171 & $1.205^{* * *}$ \\
& $(0.0430)$ & $(0.200)$ & $(0.228)$ \\
& & & \\
Observations & 572 & 388 & 213 \\
R-squared & 0.161 & 0.290 & 0.364 \\
\hline
\end{tabular}

Panel (G):

\begin{tabular}{lcc}
\hline Job-Level Pair & $\mathbf{7 8}$ & $\mathbf{7 9}$ \\
\hline \hline lg_empl & $0.0306^{* * *}$ & $0.0465^{* * *}$ \\
& $(0.00931)$ & $(0.0137)$ \\
& & \\
Constant & -0.159 & 0.191 \\
& $(0.153)$ & $(0.150)$ \\
Observations & 395 & 212 \\
R-squared & 0.298 & 0.370 \\
\hline
\end{tabular}

Panel (H):

\begin{tabular}{lc}
\hline Job-Level Pair & $\mathbf{8 9}$ \\
\hline \hline lg_empl & 0.0150 \\
& $(0.0123)$ \\
& $0.724^{* * *}$ \\
Constant & $(0.163)$ \\
& 200 \\
Observations & 0.288 \\
R-squared &
\end{tabular}




\section{Appendix Table A5 \\ Median Employment of the 50 (100) Largest Firms}

This table presents variants of the regressions in Table 10 in which firm size is measured as the median number of employees of the 50 (100) largest firms in a given country and year (in logs). The sample is the merged LISWorldscope sample described in Section 5.3. All regressions include country fixed effects. Those in columns (1) and (4) additionally include year fixed effects, while those in columns (2)-(3) and (5)-(6) include a linear time trend instead. Time trend is defined as the given year minus 1999. Robust standard errors are in parentheses. The sample period is from 1981 to 2010. *, **, and *** denotes significance at the 10\%, 5\%, and $1 \%$ level, respectively.

\begin{tabular}{|c|c|c|c|c|c|c|}
\hline & \multicolumn{3}{|c|}{ Top 50 Firms } & \multicolumn{3}{|c|}{ Top 100 Firms } \\
\hline & (1) & (2) & (3) & (4) & (5) & (6) \\
\hline \multirow[t]{2}{*}{ lg_med_empl } & $0.158 * * *$ & & $0.120 * *$ & $0.154 * * *$ & & $0.108 *$ \\
\hline & $(0.0588)$ & & $(0.0522)$ & $(0.0609)$ & & (0.0523) \\
\hline \multirow[t]{2}{*}{ time_trend } & & $0.0104^{* * *}$ & $0.00740 * * *$ & & $0.0111^{* * *}$ & $0.00859 * * *$ \\
\hline & & (0.00139) & $(0.00170)$ & & $(0.00127)$ & $(0.00146)$ \\
\hline \multirow[t]{2}{*}{ Constant } & -0.612 & $1.170 * * *$ & 0.0655 & -0.301 & $1.170 * * *$ & 0.298 \\
\hline & $(0.512)$ & $(0.0114)$ & $(0.478)$ & $(0.461)$ & $(0.00170)$ & $(0.423)$ \\
\hline Country FE & Yes & Yes & Yes & Yes & Yes & Yes \\
\hline Year FE & Yes & No & No & Yes & No & No \\
\hline Observations & 92 & 92 & 92 & 84 & 84 & 84 \\
\hline R-squared & 0.893 & 0.857 & 0.863 & 0.942 & 0.914 & 0.919 \\
\hline
\end{tabular}

